\title{
Analisis Faktor yang Berpengaruh Terhadap Terjadinya Banjir di DAS Ampal/Klandasan Besar dan Kesesuaian Program dengan Faktor Penanganannya
}

\author{
Nuur Awaliyah, Ariyaningsih, S.T., M.T, M.Sc, dan Achmad Ghozali, S.T., M.T \\ Program Studi Perencanaan Wilayah dan Kota, Jurusan Teknik Sipil dan Perencanaan \\ Institut Teknologi Kalimantan \\ e-mail: 08161061@student.itk.ac.id, ariyaningsih@lecturer.itk.ac.id, ghozali@lecturer.itk.ac.id
}

\begin{abstract}
Abstrak - Sejak tahun 2015 bencana banjir telah menjadi isu prioritas Kota Balikpapan terutama pada Daerah Aliran Sungai (DAS) Ampal. Berbagai upaya telah dilakukan oleh Pemerintah Kota Balikpapan, namun upaya tersebut belum dapat menangani banjir yang terjadi. Hal ini dapat dilihat dari jumlah kejadian banjir yang kian meningkat hingga tahun 2016. Kejadian banjir berjumlah 89 kejadian dengan 53 titik banjir. Untuk menangani permasalahan banjir, sebaiknya perlu diketahui terlebih dahulu faktor apa saja yang memengaruhi terjadinya banjir. Hal ini dilakukan agar program atau strategi yang dilaksanakan oleh pemerintah dapat tepat sasaran dalam menangani banjir yang terjadi. Penelitian ini bertujuan untuk menganalisis faktor penyebab banjir yang terjadi di DAS Ampal dan menganalisis kesesuaian program penanganan banjir yang telah dilakukan Pemerintah Kota Balikpapan berdasarkan faktor penyebabnya. Metode penelitian menggunakan pendekatan deskriptif kualitatif dengan teknik analisis Delphi dan Content dengan melibatkan 4 instansi pemerintah sebagai stakeholder kunci yaitu Dinas Pekerjaan Umum (PU) Kota Balikpapan, Dinas Lingkungan Hidup (DLH) Kota Balikpapan, Badan Perencanaan Pembangunan Daerah dan Penelitian dan Pengembangan (BAPPELITBANG) Kota Balikpapan, serta Badan Penanggulangan Bencana Daerah (BPBD) Kota Balikpapan. Hasil penelitian menunjukkan bahwa didapatkan 11 faktor internal dan 11 faktor eksternal yang memengaruhi terjadinya banjir di DAS Ampal. Diketahui pula, secara umum program yang dilaksanakan oleh pemerintah sudah sesuai dengan faktor penyebab banjir, namun terdapat beberapa program masih berupa rencana (belum ditindaklanjuti). Program tersebut berkaitan dengan faktor kapasitas sungai, kapasitas draianse, infiltrasi tanah, perencanaan sistem pengendalian banjir. Adapun rencana program tersebut terdiri dari program normalisasi Sungai Ampal, pemasangan 35 flood warning system, program kampung iklim, dan program pembangunan 13 bendali pada DAS Ampal. Selain itu, dari berbagai program yang dilakukan oleh Pemerintah Kota Balikpapan, ditemukan bahwa pemerintah belum melakukan penanganan banjir terkait faktor pemeliharaan bendali padahal faktor pemeliharaan bendali ini merupakan salah satu faktor yang memengaruhi banjir di DAS Ampal.
\end{abstract}

Kata Kunci- DAS Ampal, Faktor Penyebab, Program Penanganan

\section{PENDAHULUAN}

CEJAK tahun 2015, banjir menjadi isu prioritas lingkungan Pemerintah Kota Balikpapan, di mana pada periode 2009 sampai tahun 2015 terjadi peningkatan tutupan lahan kawasan hunian di Kota Balikpapan sebesar 13,34 [1]. Terjadi pula peningkatan genangan yang disebabkan oleh menurunnya kemampunan drainase sebesar $30 \%$ dalam menampung volume genangan setiap tahunnya [1]. Pada tahun 2016 luasan genangan di Kota Balikpapan meningkat hingga 11,34 ha [2].

Diketahui bahwa DAS Ampal terdiri dari 21 Sub DAS dengan luasan dan panjang sungai utama yang berbeda-beda [3]. Sepanjang tahun 2015, bencana banjir telah melanda Kota Balikpapan sebanyak 88 kejadian dengan 38 titik banjir berada di DAS Ampal [4]. Pada tahun 2016, kejadian banjir meningkat menjadi 89 kejadian [5]. Dari 89 kejadian tersebut, 9 Kelurahan yang dilewati DAS Ampal tergenang banjir yaitu sebanyak 53 titik banjir [6].

Pemerintah memiliki kewenangan untuk mengontrol situasi daerah rawan bencana banjir [7]. Kemampuan tersebut meliputi perencanaan dan persiapan, respon bencana, bantuan koordinasi, kebijakan rekonstruksi, dan mengatasi masalah populasi [7]. Upaya penanganan banjir di wilayah lokal difokuskan kepada pemerintah lokal (kabupaten/kota) sebagai level pertama tahap penanganan bencana banjir. Hal itu karena pemerintah lokal memiliki peran aktif dalam penanganan bencana banjir serta memiliki kebijakam dalam merespon penanganan bencana di tingkat lokal [8]. Dapat diketahui bahwa penanganan banjir di wilayah lokal merupakan tanggung jawab pemerintah lokal (kabupaten/kota) [8]. Dalam menangani permasalahan banjir yang terjadi, sebaiknya perlu diketahui terlebih dahulu faktor apa saja yang mempengaruhi terjadinya banjir. Hal ini dilakukan agar program atau strategi yang dilaksanakan oleh pemerintah dapat berhasil dan tepat sasaran dalam menangani banjir yang terjadi [9].

Oleh karena itu, dilakukan penelitian yaitu analisis faktor yang berpengaruh terhadap terjadinya banjir di DAS Ampal/Klandasan Besar guna mengetahui penyebab banjir dalam lingkup DAS Ampal agar penangangan yang dilakukan pemerintah sesuai dengan faktor penyebab banjir yang terjadi. Dilakukan pula analisis program penanganan banjir untuk mengetahui kesesuaian program penanganan banjir yang dilakukan pemerintah terhadap faktor penyebab banjir. Adapun stakeholder yang terlibat dalam penelitian ini adalah Pemerintah Kota Balikpapan yang memiliki wewenang di bidang penanganan bencana banjir di Kota Balikpapan. Stakeholder tersebut terdiri dari Dinas Pekerjaan Umum (PU), Dinas Lingkungan Hidup (DLH), 
Badan Penanggulangan Bencana Daerah (BPBD), dan Badan Perencanaan dan Penelitian Pengembangan Pembangunan Daerah (BAPELITBANG) Kota Balikpapan.

\section{METODE PENELITIAN}

Penelitian ini menggunakan pendekatan deskriptif kualitatif, pengumpulan data dilakukan secara sekunder yang diperoleh dari survei instansional dan hasil sintesis pustaka serta data primer yang diperoleh langsung dari hasil observasi. Data ini digunakan untuk mengidentifikasi faktorfaktor yang memengaruhi terjadinya banjir secara umum. Adapun teknik analisis yang dilakukan untuk menganalisis faktor yang berpengaruh terhadap terjadinya banjir di DAS Ampal adalah analisis Delphi dengan menggunakan kuesioner. Dari sintesis pustaka, diperoleh 14 faktor penyebab banjir yang terdiri dari faktor internal yaitu kapasitas sungai, kapasitas drainase, infiltrasi tanah, tinggi aliran air, debit normal, limpasan air, erosi, sedimentasi, luas DAS, bentuk DAS, topografi, morfometri, geologi, dan vegetasi. Selain itu, terdapat 10 faktor eksternal yang terdiri dari intensitas hujan, tata guna lahan, perilaku membuang sampah, kawasan kumuh, perencanaan sistem pengendalian banjir, pemeliharaan bendali, pemeliharaan drainase, lokasi permukiman di sempadan sungai, bentuk DAS, serta jarak bangunan terhadap sungai. Berdasarkan 23 faktor tersebut akan ditentukan faktor apa saja yang memengaruhi terjadinya banjir di DAS Ampal. Selain itu, teknik analisis yang dilakukan untuk menganalisis program penanganan banjir adalah analisis Content (in-depth interview). Berdasarkan analisis tersebut maka diketahui apakah program penanganan banjir yang dilakukan pemerintah telah sesuai dengan faktor penyebab banjir di DAS Ampal.

\section{HASIL DAN DISKUSI}

\section{A. Gambaran Umum DAS Ampal}

Wilayah penelitian yaitu DAS Ampal/Klandasan Besar memiliki luas sebesar 2676,9 ha yang meliputi Kecamatan Balikpapan Utara, Balikpapan Tengah, Balikpapan Selatan, dan Kecamatan Balikpapan Kota. Batas-batas administrasi DAS Ampal/Klandasan Besar adalah sebagai berikut:

- Sebelah Utara : Kelurahan Graha Indah

- Sebelah Timur: Kelurahan Gunung Bahagia

- Sebelah Barat : Kelurahan Karang Rejo dan Gunung Sari Ulu

- Sebelah Selatan: Selat Makassar

Adapun peta lokasi studi dapat dilihat pada Gambar 1 sebagai berikut

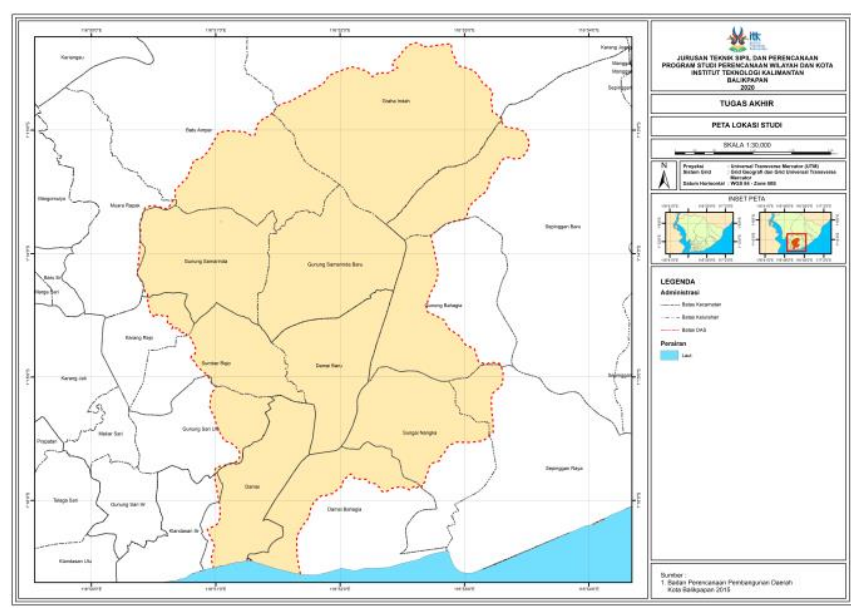

Gambar 1. Peta DAS Ampal

Sungai Ampal/Klandasan Besar memiliki panjang $4890 \mathrm{~m}$ dengan rata-rata ukuran Sungai Ampal memiliki lebar permukaan sebesar 14-27 m dan kedalaman sungai sebesar \pm $2 \mathrm{~m}$. Diketahui bahwa terdapat 1 saluran primer, 16 saluran sekunder, dan 53 saluran tersier pada DAS Ampal/Klandasan Besar [10]. Panjang total seluruh saluran sekunder adalah $31730,73 \mathrm{~m}$ dan panjang total seluruh saluran tersier adalah 56890,55 m [10]. Adapun total kapasitas saluran pada DAS Ampal ini adalah $3729,35 \mathrm{~m}^{3}$ dengan rata-rata kapasitas saluran adalah 219,37 $\mathrm{m}^{3}$. Pada kondisi hujan rata-rata normal yaitu $11 \mathrm{~mm}$, akan diperoleh limpasan air hujan yang harus ditampung pada sistem drainase Ampal sebesar $819.570 \mathrm{~m}^{3}$ [10]. Dari data tersebut juga diketahui total debit normal air yang mengalir yaitu sebesar $192 \mathrm{~m}^{3} /$ detik [10]. Oleh karena itu, dalam waktu \pm 1 jam, seharusnya limpasan air hujan tersebut sudah bisa teralirkan ke laut. Namu, berdasarkan kondisi eksisting, diketahui bahwa masih terjadi banjir di DAS Ampal. Adapun peta rawan banjir dapat dilihat pada Gambar 2 sebagai berikut.

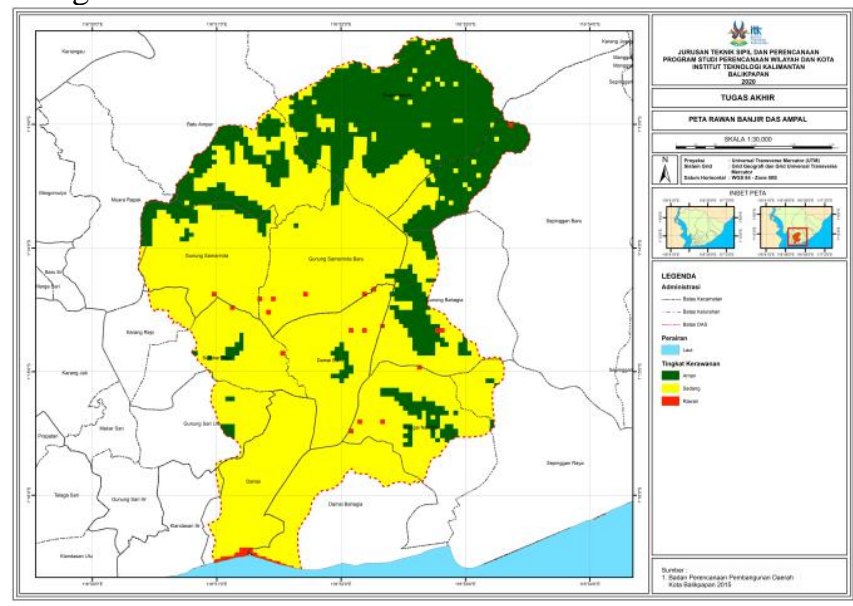

Gambar 2. Peta Titik Banjir pada DAS Ampal

\section{B. Analisis Faktor yang Berpengaruh Terhadap Terjadinya Banjir di DAS Ampal}

Pada analisis ini digunakan 24 faktor yang telah diperoleh dari tinjauan pustaka. Faktor-faktor ini digunakan sebagai input pada proses analisis faktor pengaruh terjadinya banjir di DAS Ampal/Klandasan Besar yang menggunakan teknik analisis Delphi. Analisis ini dilakukan berdasarkan tanggapan beberapa instansi pemerintahan di Kota Balikpapan. Ketika belum mencapai konsensus maka akan 
dilakukan analisis kembali (iterasi) guna mendapatkan kesepakatan terhadap faktor yang berpengaruh terhadap terjadinya banjir di DAS Ampal. Pada analisis ini dilakukan 4 kali iterasi untuk mencapai konsensus sebagai berikut.
1. Tahap Iterasi I (Eksplorasi), dari 23 faktor diperoleh bahwa 20 faktor konsensus, 2 faktor direduksi, 2 faktor diiterasi, dan 1 faktor tambahan. Faktor-faktor tersebut dapat dilihat pada tabel sebagai berikut.

Tabel 1

Hasil Kuisioner Tahap Iterasi I

\begin{tabular}{|c|c|c|c|c|c|c|c|}
\hline \multirow[t]{2}{*}{ No } & \multirow[t]{2}{*}{ Indikator } & \multirow[t]{2}{*}{ Variabel } & \multicolumn{4}{|c|}{ Instansi Pemerintah } & \multirow[t]{2}{*}{ Keterangan } \\
\hline & & & $\begin{array}{l}\text { Dinas } \\
\text { Lingkungan } \\
\text { Hidup }\end{array}$ & Dinas PU & $\begin{array}{l}\text { Badan } \\
\text { Penanggulangan } \\
\text { Bencana Daerah }\end{array}$ & BAPPELITBANG & \\
\hline \multicolumn{8}{|c|}{ Faktor Internal } \\
\hline 1. & Kondisi Sungai & Kapasitas Sungai & $\begin{array}{l}\text { S. } \\
\text { Saat ini } \\
\text { kapasitas } \\
\text { sungai tidak } \\
\text { dapat } \\
\text { menampung air } \\
\text { hujan dengan } \\
\text { intensitas tinggi }\end{array}$ & $\begin{array}{l}\text { S. } \\
\text { Terjadi } \\
\text { penyempitan dan } \\
\text { pendangkalan } \\
\text { Sungai Ampal } \\
\text { sehingga sungai } \\
\text { ini tidak dapat } \\
\text { menampung air } \\
\text { yang mengalir } \\
\text { secara maksimal. }\end{array}$ & $\begin{array}{l}\text { S. } \\
\text { Semakin lebar dan } \\
\text { dalam sungai } \\
\text { maka daya } \\
\text { tampung air akan } \\
\text { semakin besar } \\
\text { begitu pula } \\
\text { sebaliknya }\end{array}$ & $\begin{array}{l}\text { S. } \\
\text { Kapasitas Sungai } \\
\text { Ampal pada saat } \\
\text { ini belum mampu } \\
\text { menampung air } \\
\text { yang masuk ketika } \\
\text { hujan terutama } \\
\text { ketika hujan } \\
\text { dengan intensitas } \\
\text { tinggi }\end{array}$ & KONSENSUS \\
\hline 2. & Kondisi Drainase & $\begin{array}{l}\text { Kapasitas } \\
\text { Drainase }\end{array}$ & $\begin{array}{l}\text { S. } \\
\text { Kapasitas } \\
\text { drainase tidak } \\
\text { dapat } \\
\text { menampung air } \\
\text { hujan dengan } \\
\text { intensitas tinggi }\end{array}$ & $\begin{array}{l}\text { S. } \\
\text { Kapasitas } \\
\text { drainase semakin } \\
\text { kecil akibat } \\
\text { pendangkalan } \\
\text { sehingga } \\
\text { mempengaruhi } \\
\text { terjadinya banjir } \\
\text { di DAS Ampal }\end{array}$ & $\begin{array}{l}\text { S. } \\
\text { Kapasitas tidak } \\
\text { mampu } \\
\text { menampung dan } \\
\text { mengalirkan air } \\
\text { yang masuk }\end{array}$ & $\begin{array}{l}\text { S. } \\
\text { Kapasitas drainase } \\
\text { tidak dapat } \\
\text { menampung air } \\
\text { hujan dengan } \\
\text { intensitas tinggi }\end{array}$ & KONSENSUS \\
\hline 3. & Kondisi Tanah & Infiltrasi Tanah & $\begin{array}{l}\text { S. } \\
\text { Saat ini } \\
\text { kawasan } \\
\text { resapan sangat } \\
\text { kurang sekali } \\
\text { sehingga air } \\
\text { langsung } \\
\text { mengalir begitu } \\
\text { saja ke saluran } \\
\text { air dengan debit } \\
\text { yang besar }\end{array}$ & $\begin{array}{l}\text { S. } \\
\text { Kawasan resapan } \\
\text { air pada DAS } \\
\text { Ampal sangat } \\
\text { kurang, banyak } \\
\text { terjadi } \\
\text { pembukaan } \\
\text { lahan di daerah } \\
\text { hulu sedangkan } \\
\text { bagian tengah } \\
\text { dan hilir sudah } \\
\text { padat bangunan }\end{array}$ & $\begin{array}{l}\text { S. } \\
\text { Pada eksisting } \\
\text { DAS Ampal telah } \\
\text { menjadi kawasan } \\
\text { yang padat } \\
\text { bangunan } \\
\text { sehingga ketika } \\
\text { hujan akan } \\
\text { mempengaruhi } \\
\text { daya infiltrasi } \\
\text { tanah biasanya } \\
\text { daya serap tanah } \\
\text { ini bergantung } \\
\text { pada guna lahan di } \\
\text { atasnya. }\end{array}$ & $\begin{array}{l}\text { S. } \\
\text { DAS Ampal ini } \\
\text { merupakan wilayah } \\
\text { yang tergolong } \\
\text { padat sehingga } \\
\text { untuk daerah } \\
\text { resapan airnya } \\
\text { sangat kurang }\end{array}$ & KONSENSUS \\
\hline \multirow[t]{3}{*}{4.} & \multirow[t]{3}{*}{ Debit Banjir } & Tinggi Aliran Air & $\begin{array}{l}\text { S. } \\
\text { Pada DAS } \\
\text { Ampal ketika } \\
\text { hujan dengan } \\
\text { intensitas tinggi } \\
\text { maka tinggi } \\
\text { aliran air akan } \\
\text { melebihi tinggi } \\
\text { saluran } \\
\text { sehingga terjadi } \\
\text { banjir. }\end{array}$ & $\begin{array}{l}\text { S. } \\
\text { Tinggi aliran air } \\
\text { yang mengalir } \\
\text { ketika hujan } \\
\text { sangat } \\
\text { memengaruhi } \\
\text { terjadinya banjir }\end{array}$ & $\begin{array}{l}\text { S. } \\
\text { Hal ini berkaitan } \\
\text { dengan kedalaman } \\
\text { saluran, semakin } \\
\text { tinggi kedalaman } \\
\text { saluran maka } \\
\text { volume } \\
\text { tampungan } \\
\text { saluran semakin } \\
\text { besar }\end{array}$ & $\begin{array}{l}\text { S. } \\
\text { Jika intensitas } \\
\text { hujan tinggi dan } \\
\text { kecepatan air yang } \\
\text { mengalir terhambat } \\
\text { maka tinggi aliran } \\
\text { air akan mencapai } \\
\text { batas tinggi saluran } \\
\text { dan terjadilah } \\
\text { genangan atau } \\
\text { banjir }\end{array}$ & KONSENSUS \\
\hline & & Debit Normal & $\begin{array}{l}\text { T. } \\
\text { Debit normal } \\
\text { tidak akan } \\
\text { menyebabkan } \\
\text { luapan air }\end{array}$ & $\begin{array}{l}\text { T. } \\
\text { Debit normal } \\
\text { tidak akan } \\
\text { menyebabkan } \\
\text { luapan air }\end{array}$ & $\begin{array}{l}\text { T. } \\
\text { Debit normal tidak } \\
\text { akan } \\
\text { menyebabkan } \\
\text { luapan air }\end{array}$ & $\begin{array}{l}\text { T. } \\
\text { Debit normal tidak } \\
\text { akan menyebabkan } \\
\text { luapan air }\end{array}$ & REDUKSI \\
\hline & & Limpasan Air & $\begin{array}{l}\text { S. } \\
\text { Jika dilihat dari } \\
\text { eksisting, } \\
\text { limpasan air } \\
\text { hujan memang } \\
\text { tidak } \\
\text { sepenuhnya } \\
\text { dapat } \\
\text { ditampung di } \\
\end{array}$ & $\begin{array}{l}\text { S. } \\
\text { Sungai maupun } \\
\text { drainase pada } \\
\text { DAS Ampal saat } \\
\text { ini belum dapat } \\
\text { menampung } \\
\text { limpasan air } \\
\text { hujan atau } \\
\text { permukaan }\end{array}$ & $\begin{array}{l}\text { S. } \\
\text { Ketika air hujan } \\
\text { turun dan tidak } \\
\text { dapat diserap } \\
\text { tanah (kondisi } \\
\text { jenuh) dan tidak } \\
\text { dapat ditampung } \\
\text { jaringan air maka } \\
\text { air akan melimpas } \\
\end{array}$ & $\begin{array}{l}\text { S. } \\
\text { Limpasan } \\
\text { permukaan akibat } \\
\text { air hujan dapat } \\
\text { mempengaruhi } \\
\text { terjadinya banjir di } \\
\text { DAS Ampal karena } \\
\text { limpasan ini akan } \\
\text { menambah jumlah }\end{array}$ & KONSENSUS \\
\hline
\end{tabular}




\begin{tabular}{|c|c|c|c|c|c|c|c|}
\hline \multirow[t]{3}{*}{ No } & \multirow[t]{3}{*}{ Indikator } & \multirow[t]{3}{*}{ Variabel } & \multicolumn{4}{|c|}{ Instansi Pemerintah } & \multirow[t]{2}{*}{ Keterangan } \\
\hline & & & $\begin{array}{l}\text { Dinas } \\
\text { Lingkungan } \\
\text { Hidup }\end{array}$ & Dinas PU & $\begin{array}{l}\text { Badan } \\
\text { Penanggulangan } \\
\text { Bencana Daerah }\end{array}$ & BAPPELITBANG & \\
\hline & & & $\begin{array}{l}\text { sistem jaringan } \\
\text { atau saluran air } \\
\text { DAS Ampal }\end{array}$ & $\begin{array}{l}\text { secara maksimal } \\
\text { karena kurang } \\
\text { besarnya } \\
\text { kapasitas saluran } \\
\text { air tersebut }\end{array}$ & $\begin{array}{l}\text { dan menimbulkan } \\
\text { genangan }\end{array}$ & $\begin{array}{l}\text { debit air yang harus } \\
\text { ditampung oleh } \\
\text { saluran air }\end{array}$ & \\
\hline \multirow[t]{2}{*}{5.} & \multirow[t]{2}{*}{$\begin{array}{l}\text { Kapasitas } \\
\text { Sungai/Drainase }\end{array}$} & Erosi & $\begin{array}{l}\text { S. } \\
\text { Terjadi } \\
\text { pembukaan } \\
\text { lahan di daerah } \\
\text { hulu } \\
\text { menyebabkan } \\
\text { berkurangnya } \\
\text { daerah resapan } \\
\text { air, ketika } \\
\text { hujan terjadi } \\
\text { erosi yang } \\
\text { terbawa hingga } \\
\text { ke hilir menjadi } \\
\text { endapan } \\
\text { (sedimentasi) } \\
\text { sehingga hal ini } \\
\text { memengaruhi } \\
\text { daya tampung } \\
\text { saluran air }\end{array}$ & $\begin{array}{l}\text { S. } \\
\text { Pengikisan yang } \\
\text { terjadi di bagian } \\
\text { hulu Sungai } \\
\text { Ampal } \\
\text { menyebabkan } \\
\text { sedimentasi di } \\
\text { beberapa titik. } \\
\text { Hal ini } \\
\text { memengaruhi } \\
\text { kapasitas sungai } \\
\text { dalam } \\
\text { menampung } \\
\text { debit air dan } \\
\text { dapat } \\
\text { memengaruhi } \\
\text { kecepatan aliran } \\
\text { air. }\end{array}$ & $\begin{array}{l}\text { S. } \\
\text { Erosi dan } \\
\text { sedimentasi ini } \\
\text { saling berkaitan, } \\
\text { semakin besar } \\
\text { erosi yang terjadi } \\
\text { maka semakin } \\
\text { besar pula } \\
\text { sedimentasi yang } \\
\text { ada. Pada DAS } \\
\text { Ampal, kedua hal } \\
\text { ini sangat } \\
\text { memengaruhi } \\
\text { terjadinya banjir } \\
\text { karena dari } \\
\text { sedimentasi yang } \\
\text { terjadi dapat } \\
\text { menyebabkan } \\
\text { pendangkalan } \\
\text { saluran air }\end{array}$ & $\begin{array}{l}\text { S. } \\
\text { Erosi merupakan } \\
\text { proses pengikisan } \\
\text { material tanah yang } \\
\text { biasanya terbawa } \\
\text { aliran air kemudian } \\
\text { mengendap. } \\
\text { Endapan pasir ini } \\
\text { akan memengaruhi } \\
\text { daya tampung } \\
\text { saluran air, karena } \\
\text { saluran air menjadi } \\
\text { dangkal. }\end{array}$ & KONSENSUS \\
\hline & & Sedimentasi & $\begin{array}{l}\text { S. } \\
\text { Terjadi } \\
\text { pembukaan } \\
\text { lahan didaerah } \\
\text { hulu } \\
\text { menyebabkan } \\
\text { berkurangnya } \\
\text { daerah resapan } \\
\text { air, ketika } \\
\text { hujan terjadi } \\
\text { erosi yang } \\
\text { terbawa hingga } \\
\text { ke hilir menjadi } \\
\text { endapan } \\
\text { (sedimentasi) } \\
\text { sehingga hal ini } \\
\text { memengaruhi } \\
\text { daya tampung } \\
\text { saluran air }\end{array}$ & $\begin{array}{l}\text { S. } \\
\text { Pengikisan yang } \\
\text { terjadi dibagian } \\
\text { hulu Sungai } \\
\text { Ampal } \\
\text { menyebabkan } \\
\text { sedimentasi di } \\
\text { beberapa titik. } \\
\text { Hal ini } \\
\text { memengaruhi } \\
\text { kapasitas sungai } \\
\text { dalam } \\
\text { menampung } \\
\text { debit air dan } \\
\text { dapat } \\
\text { memengaruhi } \\
\text { kecepatan aliran } \\
\text { air. }\end{array}$ & $\begin{array}{l}\text { S. } \\
\text { Erosi dan } \\
\text { sedimentasi ini } \\
\text { saling berkaitan, } \\
\text { semakin besar } \\
\text { erosi yang terjadi } \\
\text { maka semakin } \\
\text { besar pula } \\
\text { sedimentasi yang } \\
\text { ada }\end{array}$ & $\begin{array}{l}\text { S. } \\
\text { Erosi merupakan } \\
\text { proses pengikisan } \\
\text { material tanah yang } \\
\text { biasanya terbawa } \\
\text { aliran air kemudian } \\
\text { mengendap. } \\
\text { Endapan pasir ini } \\
\text { akan memengaruhi } \\
\text { daya tampung } \\
\text { saluran air, karena } \\
\text { saluran air menjadi } \\
\text { dangkal. Oleh } \\
\text { karena itu hal ini } \\
\text { dapat memengaruhi } \\
\text { terjadinya banjir di } \\
\text { DAS Ampal }\end{array}$ & KONSENSUS \\
\hline \multirow[t]{2}{*}{6.} & \multirow[t]{2}{*}{ Karakteristik DAS } & Luas DAS & $\begin{array}{l}\text { S. } \\
\text { Semakin luas } \\
\text { DAS maka } \\
\text { akan semakin } \\
\text { sulit untuk } \\
\text { mengalirkan air } \\
\text { ke hilir atau } \\
\text { laut, jika } \\
\text { kondisi DAS } \\
\text { tidak didukung } \\
\text { perencanaan } \\
\text { yang baik }\end{array}$ & $\begin{array}{l}\text { S. } \\
\text { Jika DAS } \\
\text { semakin besar } \\
\text { maka proses air } \\
\text { menuju laut } \\
\text { tidak secepat } \\
\text { DAS yang } \\
\text { memiliki luasan } \\
\text { yang kecil. } \\
\text { Artinya terdapat } \\
\text { potensi } \\
\text { terjadinya } \\
\text { genangan di } \\
\text { beberapa titik } \\
\text { wilayah DAS } \\
\text { yang luas. } \\
\text { Namun hal ini } \\
\text { juga dipengaruhi } \\
\text { guna lahan di } \\
\text { sekitar DAS }\end{array}$ & $\begin{array}{l}\text { S. } \\
\text { Semakin luas DAS } \\
\text { maka semakin } \\
\text { besar juga } \\
\text { kemungkinan } \\
\text { DAS ini menjadi } \\
\text { kawasan rawan } \\
\text { banjir. Apalagi } \\
\text { jika penggunaan } \\
\text { lahan wilayah } \\
\text { DAS ini lebih } \\
\text { banyak menjadi } \\
\text { kawasan } \\
\text { terbangun }\end{array}$ & $\begin{array}{l}\text { S. } \\
\text { Semakin luas DAS } \\
\text { maka semakin } \\
\text { besar pula } \\
\text { kemungkinan } \\
\text { terjadinya banjir. } \\
\text { Hal ini dilihat dari } \\
\text { kondisi DAS di } \\
\text { mana diketahui } \\
\text { bahwa luas DAS } \\
\text { tidak sama dengan } \\
\text { luas catchment } \\
\text { area. }\end{array}$ & KONSENSUS \\
\hline & & Bentuk DAS & $\begin{array}{l}\text { S. } \\
\text { Bentuk DAS } \\
\text { memengaruhi } \\
\text { terjadinya } \\
\text { banjir karena } \\
\text { berkaitan } \\
\text { dengan } \\
\text { kecepatan }\end{array}$ & $\begin{array}{l}\text { S. } \\
\text { Bentuk DAS } \\
\text { berpengaruh } \\
\text { terhadap } \\
\text { kecepatan aliran } \\
\text { air }\end{array}$ & $\begin{array}{l}\text { S. } \\
\text { Bentuk DAS } \\
\text { memengaruhi } \\
\text { terjadinya banjir } \\
\text { karena berkaitan } \\
\text { dengan kecepatan } \\
\text { aliran air menuju } \\
\text { laut }\end{array}$ & $\begin{array}{l}\text { T. } \\
\text { Tergantung luasan } \\
\text { catchment area di } \\
\text { sekitar DAS }\end{array}$ & ITERASI \\
\hline
\end{tabular}




\begin{tabular}{|c|c|c|c|c|c|c|c|}
\hline \multirow[t]{6}{*}{ No } & \multirow[t]{6}{*}{ Indikator } & \multirow[t]{3}{*}{ Variabel } & \multicolumn{4}{|c|}{ Instansi Pemerintah } & \multirow[t]{2}{*}{ Keterangan } \\
\hline & & & $\begin{array}{l}\text { Dinas } \\
\text { Lingkungan } \\
\text { Hidup }\end{array}$ & Dinas PU & $\begin{array}{l}\text { Badan } \\
\text { Penanggulangan } \\
\text { Bencana Daerah }\end{array}$ & BAPPELITBANG & \\
\hline & & & $\begin{array}{l}\text { aliran air } \\
\text { menuju laut }\end{array}$ & & & & \\
\hline & & Topografi & $\begin{array}{l}\text { S. } \\
\text { Hal ini } \\
\text { berkaitan } \\
\text { dengan tinggi } \\
\text { rendahnya } \\
\text { kontur bagian } \\
\text { hulu, tengah, } \\
\text { dan hilir DAS. } \\
\text { Semakin rendah } \\
\text { kontur wilayah } \\
\text { pada suatu } \\
\text { DAS maka } \\
\text { biasanya } \\
\text { wilayah } \\
\text { tersebut rawan } \\
\text { banjir. }\end{array}$ & $\begin{array}{l}\text { S. } \\
\text { Hal ini berkaitan } \\
\text { dengan tinggi } \\
\text { rendahnya kontur } \\
\text { bagian hulu, } \\
\text { tengah, dan hilir } \\
\text { DAS. Semakin } \\
\text { rendah kontur } \\
\text { wilayah pada } \\
\text { suatu DAS maka } \\
\text { biasanya wilayah } \\
\text { tersebut rawan } \\
\text { banjir. }\end{array}$ & $\begin{array}{l}\text { S. } \\
\text { Topografi dapat } \\
\text { memengaruhi } \\
\text { terjadinya banjir } \\
\text { di DAS Ampal } \\
\text { karena hal in } \\
\text { berkaitan dengan } \\
\text { kontur saluran air } \\
\text { dari hulu hingga } \\
\text { ke hilir. Wilayah } \\
\text { dengan topografi } \\
\text { rendah berada di } \\
\text { daerah hilir dan } \\
\text { biasanya wilayah } \\
\text { ini menjadi } \\
\text { kawasan yang } \\
\text { rawan banjir }\end{array}$ & $\begin{array}{l}\text { S. } \\
\text { Titik banjir pada } \\
\text { DAS Ampal berada } \\
\text { tersebar dari daerah } \\
\text { hulu hingga hilir. } \\
\text { Namun kejadian } \\
\text { banjir yang sering } \\
\text { terjadi berada di } \\
\text { hilir sungai, hal ini } \\
\text { dipengaruhi oleh } \\
\text { topografi DAS } \\
\text { Ampal. Bagian } \\
\text { hilir DAS } \\
\text { merupakan wilayah } \\
\text { rendah dan } \\
\text { dipengaruh pula } \\
\text { oleh pasang surut } \\
\text { air laut }\end{array}$ & KONSENSUS \\
\hline & & Morfometri & $\begin{array}{l}\text { S. } \\
\text { Biasanya } \\
\text { bentuk } \\
\text { penampang } \\
\text { saluran sungai } \\
\text { atau drainase } \\
\text { yang masih } \\
\text { alami ini } \\
\text { dipengaruhi } \\
\text { oleh topografi } \\
\text { atau kontur di } \\
\text { wilayah } \\
\text { tersebut. } \\
\text { Sehingga } \\
\text { ukurannya } \\
\text { berbeda-beda } \\
\text { (daya } \\
\text { tampungnya } \\
\text { berbeda pula) } \\
\text { dan dapat } \\
\text { mempengaruhi } \\
\text { terjadinya } \\
\text { banjir di DAS } \\
\text { Ampal }\end{array}$ & $\begin{array}{l}\text { S. } \\
\text { Morfometri } \\
\text { saluran pada } \\
\text { DAS Ampal } \\
\text { dilihat dari segi } \\
\text { bentuk dan } \\
\text { dimensi, maka } \\
\text { tiap saluran akan } \\
\text { memiliki } \\
\text { morfometri yang } \\
\text { berbeda. }\end{array}$ & $\begin{array}{l}\text { S. } \\
\text { Bagian hulu dan } \\
\text { hilir DAS } \\
\text { memiliki } \\
\text { morfometri yang } \\
\text { berbeda hal ini } \\
\text { dipengaruhi oleh } \\
\text { kondisi saluran } \\
\text { yang berkaitan } \\
\text { dengan ada } \\
\text { tidaknya sedimen. } \\
\text { Tidak seluruh } \\
\text { saluran memiliki } \\
\text { bentuk saluran } \\
\text { yang sama, bisa } \\
\text { jadi berbeda beda } \\
\text { akibat sedimen } \\
\text { yang terjadi }\end{array}$ & $\begin{array}{l}\text { S. } \\
\text { Teori } \\
\text { Morfometri ini } \\
\text { sama seperti } \\
\text { kapasitas, dimana } \\
\text { bentuk saluran } \\
\text { sungai/drainase ini } \\
\text { juga dipengaruhi } \\
\text { oleh kondisi } \\
\text { topografi. Jadi } \\
\text { dimensi saluran } \\
\text { bagian hulu hingga } \\
\text { hilir berbeda-beda } \\
\text { artinya } \\
\text { kapasitasnya } \\
\text { berbeda-beda pula. }\end{array}$ & KONSENSUS \\
\hline & & Geologi & $\begin{array}{l}\text { T. } \\
\text { Jenis batuan } \\
\text { tidak } \\
\text { memengaruhi } \\
\text { banjir di DAS } \\
\text { Ampal. Secara } \\
\text { umum kondisi } \\
\text { geologi dapat } \\
\text { memengaruhi } \\
\text { terjadinya } \\
\text { banjir karena } \\
\text { hal ini } \\
\text { berkaitan } \\
\text { dengan jenis } \\
\text { batuan yang } \\
\text { ada yang dapat } \\
\text { menyebabkan } \\
\text { endapan } \\
\text { sedimen. } \\
\text { Namun } \\
\text { endapan } \\
\text { sedimen pada } \\
\text { DAS Ampal } \\
\text { terjadi karena } \\
\text { guna lahan di } \\
\text { DAS Ampal } \\
\text { yang kurang } \\
\text { akan lahan }\end{array}$ & $\begin{array}{l}\text { T. } \\
\text { Untuk kondisi } \\
\text { geologi lebih } \\
\text { memengaruhi } \\
\text { terjadinya tanah } \\
\text { longsor di DAS } \\
\text { Ampal maupun } \\
\text { di Kota } \\
\text { Balikpapan. }\end{array}$ & $\begin{array}{l}\text { T. } \\
\text { Untuk kondisi } \\
\text { geologi di DAS } \\
\text { Ampal tidak } \\
\text { memengaruhi } \\
\text { banjir, infiltrasi } \\
\text { tanah lebih } \\
\text { mempengaruhi } \\
\text { banjir. Jika daya } \\
\text { serap tanah di } \\
\text { sekitar DAS dalam } \\
\text { menyimpan air } \\
\text { rendah maka akan } \\
\text { memicu } \\
\text { banyaknya jumlah } \\
\text { air yang masuk ke } \\
\text { sungai. }\end{array}$ & $\begin{array}{l}\text { T. } \\
\text { Kondisi geologi ini } \\
\text { berarti berkaitan } \\
\text { dengan jenis } \\
\text { batuan. Secara } \\
\text { tidak langsung, } \\
\text { jenis batuan } \\
\text { tertentu dapat } \\
\text { memengaruhi } \\
\text { mudahnya terjadi } \\
\text { erosi dan } \\
\text { sedimentasi. } \\
\text { Namun untuk DAS } \\
\text { Ampal } \\
\text { kondisi geologi } \\
\text { tidak memengaruhi } \\
\text { terjadinya banjir } \\
\text { secara langsung, } \\
\text { karena infiltrasi } \\
\text { tanah yang } \\
\text { berkaitan dengan } \\
\text { daerah tangkapan } \\
\text { air di sekitar DAS } \\
\text { lebih memengaruhi } \\
\text { terjadinya banjir. }\end{array}$ & REDUKSI \\
\hline
\end{tabular}




\begin{tabular}{|c|c|c|c|c|c|c|c|}
\hline \multirow[t]{4}{*}{ No } & \multirow[t]{4}{*}{ Indikator } & \multirow[t]{2}{*}{ Variabel } & \multicolumn{4}{|c|}{ Instansi Pemerintah } & \multirow[t]{2}{*}{ Keterangan } \\
\hline & & & $\begin{array}{l}\text { Dinas } \\
\text { Lingkungan } \\
\text { Hidup }\end{array}$ & Dinas PU & $\begin{array}{l}\text { Badan } \\
\text { Penanggulangan } \\
\text { Bencana Daerah }\end{array}$ & BAPPELITBANG & \\
\hline & & & resapan air. & & & & \\
\hline & & Vegetasi & $\begin{array}{l}\text { S. } \\
\text { Vegetasi dapat } \\
\text { menjadi } \\
\text { kawasan } \\
\text { resapan air } \\
\text { guna } \\
\text { memperkecil } \\
\text { jumlah air yang } \\
\text { masuk ke } \\
\text { saluran air }\end{array}$ & $\begin{array}{l}\text { S. } \\
\text { Vegetasi pada } \\
\text { DAS Ampal } \\
\text { sangat sedikit } \\
\text { luasannya, } \\
\text { karena sempadan } \\
\text { sungai } \\
\text { didominasi oleh } \\
\text { bangunan }\end{array}$ & $\begin{array}{l}\text { S. } \\
\text { Adanya vegetasi } \\
\text { dapat } \\
\text { memperbesar } \\
\text { jumlah air yang } \\
\text { terserap oleh tanah } \\
\text { sehingga hal ini } \\
\text { membantu } \\
\text { sungai/drainase } \\
\text { karena dapat } \\
\text { memperkecil } \\
\text { jumlah air yang } \\
\text { ditampung }\end{array}$ & $\begin{array}{l}\text { S. } \\
\text { Vegetasi dapat } \\
\text { mempengaruhi } \\
\text { terjadinya banjir } \\
\text { karena adanya } \\
\text { vegetasi dapat } \\
\text { memperkecil } \\
\text { limpasan } \\
\text { permukaan, jika } \\
\text { tidak ada vegetasi } \\
\text { maka debit } \\
\text { limpasan yang } \\
\text { masuk ke } \\
\text { sungai/drainase } \\
\text { akan semakin besar }\end{array}$ & KONSENSUS \\
\hline \multicolumn{8}{|c|}{ Faktor Eksternal } \\
\hline 1. & Curah Hujan & Intensitas Hujan & $\begin{array}{l}\text { S. } \\
\text { Dapat } \\
\text { dikatakan } \\
\text { bahwa Kota } \\
\text { Balikpapan } \\
\text { sekarang ini } \\
\text { sensitif } \\
\text { terhadap hujan } \\
\text { karena hujan } \\
\text { yang tidak } \\
\text { berlangsung } \\
\text { lama pun bisa } \\
\text { menyebabkan } \\
\text { banjir. }\end{array}$ & $\begin{array}{l}\text { S. } \\
\text { Hujan sangat } \\
\text { memengaruhi } \\
\text { banjir di DAS } \\
\text { Ampal, } \\
\text { berdasarkan } \\
\text { eksisting banjir } \\
\text { yang terjadi pada } \\
\text { DAS ini memang } \\
\text { disebabkan oleh } \\
\text { curah dan } \\
\text { intensitas hujan } \\
\text { yang tinggi }\end{array}$ & $\begin{array}{l}\text { S. } \\
\text { Curah hujan dapat } \\
\text { memengaruhi } \\
\text { terjadinya banjir } \\
\text { di DAS Ampal } \\
\text { Hal ini dapat } \\
\text { dilihat pada } \\
\text { eksisting di mana } \\
\text { pada tahun } 2020 \\
\text { hingga bulan } \\
\text { Februari telah } \\
\text { terjadi banjir } \\
\text { sebanyak 13 kali } \\
\text { akibat curah hujan } \\
\text { yang tinggi }\end{array}$ & $\begin{array}{l}\text { S. } \\
\text { Jika curah hujan di } \\
\text { atas } 200 \mathrm{~mm} \text { maka } \\
\text { dalam hitungan } \\
\text { jam, beberapa titik } \\
\text { di DAS Ampal } \\
\text { langsung tergenang } \\
\text { air hujan }\end{array}$ & KONSENSUS \\
\hline \multirow[t]{2}{*}{2.} & \multirow[t]{2}{*}{ Aktivitas Manusia } & Tata Guna Lahan & $\begin{array}{l}\text { Tata guna lahan } \\
\text { di DAS Ampal } \\
\text { didominasi oleh } \\
\text { permukiman } \\
\text { padat dan pada } \\
\text { permukiman } \\
\text { tersebut RTH } \\
\text { yang dimiliki } \\
\text { kurang dari } \\
\text { 30\% artinya } \\
\text { DAS Ampal ini } \\
\text { kurang } \\
\text { memiliki } \\
\text { kawasan } \\
\text { resapan air. Hal } \\
\text { ini dapat } \\
\text { memperbesar } \\
\text { debit air } \\
\text { menuju sungai } \\
\text { karena jumlah } \\
\text { air yang diserap } \\
\text { tanah tidak. }\end{array}$ & $\begin{array}{l}\text { Tata guna lahan } \\
\text { ini dapat } \\
\text { memengaruhi } \\
\text { terjadinya banjir } \\
\text { di DAS Ampal } \\
\text { karena dapat } \\
\text { dilihat pada } \\
\text { kondisi eksisting } \\
\text { di sekitar Sungai } \\
\text { Ampal itu } \\
\text { didominasi oleh } \\
\text { permukiman } \\
\text { bahkan langsung } \\
\text { bersinggungan } \\
\text { dengan sungai } \\
\text { sehingga tidak } \\
\text { memiliki } \\
\text { sempadan. } \\
\text { Seharusnya guna } \\
\text { lahan disekitar } \\
\text { sungai tersebut } \\
\text { adalah lahan } \\
\text { hijau untuk } \\
\text { meminimalisasi } \\
\text { debit air yang } \\
\text { masuk ke } \\
\text { sungai/drainase }\end{array}$ & $\begin{array}{l}\text { Di DAS Ampal } \\
\text { banyak terjadi } \\
\text { pengupasan lahan } \\
\text { pada bagian hulu } \\
\text { untuk menjadi } \\
\text { kawasan } \\
\text { permukiman. Hal } \\
\text { ini berpengaruh } \\
\text { terhadap } \\
\text { terjadinya banjir } \\
\text { karena ketika hulu } \\
\text { sungai tidak } \\
\text { memiliki lahan } \\
\text { hijau untuk } \\
\text { meresap air maka } \\
\text { jumlah erosi dan } \\
\text { sedimentasi akan } \\
\text { semakin } \\
\text { meningkat dan } \\
\text { akhirnya } \\
\text { mempengaruhi } \\
\text { tampungan } \\
\text { sungai/drainase }\end{array}$ & $\begin{array}{l}\text { Penggunaan lahan } \\
\text { di DAS Ampal ini } \\
\text { tergolong padat } \\
\text { bangunan sehingga } \\
\text { memengaruhi } \\
\text { tingkat infiltrasi } \\
\text { tanah. Jika daerah } \\
\text { resapan air kurang } \\
\text { karena banyaknya } \\
\text { lahan terbangun } \\
\text { maka debit air } \\
\text { hujan yang harus } \\
\text { ditampung } \\
\text { sungai/drainase } \\
\text { menjadi besar. }\end{array}$ & KONSENSUS \\
\hline & & $\begin{array}{l}\text { Perilaku } \\
\text { Membuang } \\
\text { Sampah }\end{array}$ & $\begin{array}{l}\text { S. } \\
\text { Perilaku } \\
\text { masyarakat } \\
\text { dalam } \\
\text { membuang } \\
\text { sampah masih } \\
\text { buruk karena } \\
\text { masih ada } \\
\text { masyarakat } \\
\text { yang } \\
\text { membuang } \\
\text { sampah di } \\
\text { saluran air }\end{array}$ & $\begin{array}{l}\text { S. } \\
\text { Semakin banyak } \\
\text { masyarakat yang } \\
\text { membuang } \\
\text { sampah di sungai } \\
\text { maka timbulan } \\
\text { sampah semakin } \\
\text { besar pula dan } \\
\text { akan } \\
\text { menghambat } \\
\text { aliran air di } \\
\text { sungai }\end{array}$ & $\begin{array}{l}\text { S. } \\
\text { Perilaku } \\
\text { membuang } \\
\text { sampah ini } \\
\text { terutama } \\
\text { membuang } \\
\text { sampah di Sungai } \\
\text { Ampal dapat } \\
\text { mempengaruhi } \\
\text { terjadinya banjir } \\
\text { karena sampah- } \\
\text { sampah tersebut } \\
\text { dapat }\end{array}$ & $\begin{array}{l}\text { S. } \\
\text { Berdasarkan } \\
\text { eksisting, masih } \\
\text { terdapat sampah- } \\
\text { sampah di Sungai } \\
\text { Ampal terutama di } \\
\text { bagian hilir sungai } \\
\text { karena sampah dari } \\
\text { hulu akan ikut } \\
\text { mengalir ke bagian } \\
\text { hilir kemudian } \\
\text { masuk ke laut. } \\
\text { Banyaknya sampah }\end{array}$ & KONSENSUS \\
\hline
\end{tabular}




\begin{tabular}{|c|c|c|c|c|c|c|c|}
\hline \multirow[t]{6}{*}{ No } & \multirow[t]{6}{*}{ Indikator } & \multirow[t]{2}{*}{ Variabel } & \multicolumn{4}{|c|}{ Instansi Pemerintah } & \multirow[t]{2}{*}{ Keterangan } \\
\hline & & & $\begin{array}{l}\text { Dinas } \\
\text { Lingkungan } \\
\text { Hidup }\end{array}$ & Dinas PU & $\begin{array}{l}\text { Badan } \\
\text { Penanggulangan } \\
\text { Bencana Daerah }\end{array}$ & BAPPELITBANG & \\
\hline & & & $\begin{array}{l}\text { (sungai/drainas } \\
\text { e) }\end{array}$ & & $\begin{array}{l}\text { menghambat arus } \\
\text { air di sungai } \\
\text { sehingga air } \\
\text { sungai dapat } \\
\text { meluap }\end{array}$ & $\begin{array}{l}\text { di daerah hilir juga } \\
\text { dikarenakan } \\
\text { terdapat } \\
\text { permukiman yang } \\
\text { bersinggungan } \\
\text { dengan sungai } \\
\text { sehingga } \\
\text { kemungkinan } \\
\text { masyarakat } \\
\text { membuang sampah } \\
\text { langsung ke sungai } \\
\text { sangat besar. } \\
\end{array}$ & \\
\hline & & Kawasan Kumuh & $\begin{array}{l}\text { S. } \\
\text { Jika ada } \\
\text { kawasan kumuh } \\
\text { maka } \\
\text { kemungkinan } \\
\text { akan banyak } \\
\text { sampah yang } \\
\text { dibuang ke } \\
\text { sungai dari } \\
\text { kawasan } \\
\text { tersebut } \\
\text { sehingga dapat } \\
\text { menghambat } \\
\text { aliran air }\end{array}$ & $\begin{array}{l}\text { S. } \\
\text { Kawasan kumuh } \\
\text { di sekitar sungai } \\
\text { dapat } \\
\text { mempengaruhi } \\
\text { kapasitas } \\
\text { sungai/drainase } \\
\text { karena akan } \\
\text { mempersempit } \\
\text { kapasitas dan } \\
\text { memperbesar } \\
\text { pendangkalan } \\
\text { yang terjadi. }\end{array}$ & $\begin{array}{l}\text { S. Adanya } \\
\text { kawasan ini dapat } \\
\text { mengganggu } \\
\text { aliran air sehingga } \\
\text { kinerja saluran air } \\
\text { tidak optimal. }\end{array}$ & $\begin{array}{l}\text { S. } \\
\text { Saat ini pada DAS } \\
\text { Ampal terdapat } \\
\text { permukiman } \\
\text { kumuh terutama di } \\
\text { hilir sungai, di } \\
\text { mana kawasan ini } \\
\text { dibangun } \\
\text { bersinggungan } \\
\text { dengan sungai. Hal } \\
\text { ini dapat } \\
\text { memengaruhi } \\
\text { terjadinya banjir } \\
\text { karena kawasan } \\
\text { tersebut dapat } \\
\text { memperbesar } \\
\text { timbulan sampah } \\
\text { di sungai dan } \\
\text { menghambat aliran } \\
\text { air sungai }\end{array}$ & KONSENSUS \\
\hline & & $\begin{array}{l}\text { Perencanaan } \\
\text { Sistem } \\
\text { Pengendalian } \\
\text { Banjir }\end{array}$ & $\begin{array}{l}\text { S. } \\
\text { Salah satu } \\
\text { upaya } \\
\text { perencanaan } \\
\text { sistem } \\
\text { pengendalian } \\
\text { banjir yang } \\
\text { dicanangkan } \\
\text { pemerintah saat } \\
\text { ini adalah } \\
\text { normalisasi } \\
\text { Sungai Ampal. } \\
\text { Sistem } \\
\text { pengendalian } \\
\text { banjir ini } \\
\text { dibutuhkan } \\
\text { untuk } \\
\text { mengatasi } \\
\text { permasalahan } \\
\text { banjir yang } \\
\text { terjadi }\end{array}$ & $\begin{array}{l}\text { S. } \\
\text { Saat ini } \\
\text { perencanaan } \\
\text { sistem } \\
\text { pengendalian } \\
\text { banjir dilakukan } \\
\text { dengan } \\
\text { penambahan } \\
\text { pembangunan } \\
\text { bendali dan } \\
\text { pembebasan } \\
\text { lahan untuk } \\
\text { normalisasi } \\
\text { Sungai Ampal. } \\
\text { Dengan } \\
\text { perencanaan } \\
\text { yang tepat maka } \\
\text { banjir dapat } \\
\text { diatasi }\end{array}$ & $\begin{array}{l}\text { S. } \\
\text { Guna menangani } \\
\text { masalah banjir di } \\
\text { DAS Ampal maka } \\
\text { dibutuhkan } \\
\text { perencanaan } \\
\text { sistem } \\
\text { pengendalian } \\
\text { banjir. } \\
\text { Perencanaan ini } \\
\text { harus tepat sasaran } \\
\text { jika tidak maka } \\
\text { upaya } \\
\text { pengendalian akan } \\
\text { sia-sia }\end{array}$ & $\begin{array}{l}\text { S. } \\
\text { Perencanaan sistem } \\
\text { pengendalian } \\
\text { banjir ini harus } \\
\text { dilakukan dengan } \\
\text { tepat, jika tidak } \\
\text { maka banjir masih } \\
\text { akan terjadi. Salah } \\
\text { satu contoh upaya } \\
\text { perencanaan sistem } \\
\text { pengendalian } \\
\text { banjir di DAS } \\
\text { Ampal yang akan } \\
\text { dilaksanakan yaitu } \\
\text { normalisasi sungai } \\
\text { dan pembangunan } \\
\text { bendali. Hal ini } \\
\text { membutuhkan } \\
\text { perencanaan yang } \\
\text { matang agar dapat } \\
\text { memberikan } \\
\text { dampak } \\
\text { pengurangan } \\
\text { potensi banjir } \\
\text { secara signifikan }\end{array}$ & KONSENSUS \\
\hline & & $\begin{array}{l}\text { Pemeliharaan } \\
\text { Bendali }\end{array}$ & $\begin{array}{l}\text { S. } \\
\text { Ketidakmampu } \\
\text { an sungai } \\
\text { dalam } \\
\text { menampung } \\
\text { debit air dapat } \\
\text { dibantu dengan } \\
\text { adanya bendali. } \\
\text { Sehingga } \\
\text { bendali } \\
\text { memiliki peran } \\
\text { penting dalam } \\
\text { mengendalikan } \\
\text { aliran air. Oleh } \\
\text { karena itu } \\
\end{array}$ & $\begin{array}{l}\text { S. } \\
\text { Pemelihataan } \\
\text { bendali sangat } \\
\text { penting untuk } \\
\text { dilakukan karena } \\
\text { jika bendali tidak } \\
\text { dipelihara maka } \\
\text { kinerja bendali } \\
\text { tidak dapat } \\
\text { berjalan optimal } \\
\text { dan } \\
\text { menyebabkan } \\
\text { aliran air yang } \\
\text { masuk ke Sungai } \\
\text { Ampal tidak } \\
\end{array}$ & $\begin{array}{l}\text { S. } \\
\text { Pemeliharaan } \\
\text { bendali dapat } \\
\text { mempengaruhi } \\
\text { terjadinya banjir } \\
\text { karena jika } \\
\text { bendali dapat } \\
\text { digunakan secara } \\
\text { optimal maka } \\
\text { resiko terjadinya } \\
\text { banjir dapat } \\
\text { diperkecil. Hal ini } \\
\text { dapat diketahui } \\
\text { dari fungsi bendali } \\
\text { yaitu menampung }\end{array}$ & $\begin{array}{l}\text { S. } \\
\text { Guna } \\
\text { mengendalikan } \\
\text { aliran air dari hulu } \\
\text { ke hilir maka } \\
\text { dibangunlah } \\
\text { bendali. Pada DAS } \\
\text { Ampal terdapat } 3 \\
\text { bendali yang sudah } \\
\text { terbangun namun } \\
\text { untuk saat ini } \\
\text { bendali Wonorejo } \\
\text { belum dapat } \\
\text { berfungsi } \\
\text { maksimal. Oleh }\end{array}$ & KONSENSUS \\
\hline
\end{tabular}




\begin{tabular}{|c|c|c|c|c|c|c|c|}
\hline \multirow[t]{4}{*}{ No } & \multirow[t]{4}{*}{ Indikator } & \multirow[t]{2}{*}{ Variabel } & \multicolumn{4}{|c|}{ Instansi Pemerintah } & \multirow[t]{2}{*}{ Keterangan } \\
\hline & & & $\begin{array}{l}\text { Dinas } \\
\text { Lingkungan } \\
\text { Hidup }\end{array}$ & Dinas PU & $\begin{array}{l}\text { Badan } \\
\text { Penanggulangan } \\
\text { Bencana Daerah }\end{array}$ & BAPPELITBANG & \\
\hline & & & $\begin{array}{l}\text { bendali harus } \\
\text { tetap terpelihara }\end{array}$ & $\begin{array}{l}\text { dapat } \\
\text { dikendalikan }\end{array}$ & $\begin{array}{l}\text { dan menghambat } \\
\text { aliran air di hulu } \\
\text { agar debit air } \\
\text { menuju hilir tidak } \\
\text { terlalu besar, } \\
\text { artinya debit air } \\
\text { hujan yang masuk } \\
\text { kedalam saluran } \\
\text { dapat dikontrol }\end{array}$ & $\begin{array}{l}\text { karena itu } \\
\text { pemeliharaan ini } \\
\text { penting agar aliran } \\
\text { air dapat } \\
\text { dikendalikan }\end{array}$ & \\
\hline & & $\begin{array}{l}\text { Pemeliharaan } \\
\text { Drainase }\end{array}$ & $\begin{array}{l}\text { S. } \\
\text { Pemeliharaan } \\
\text { drainase perlu } \\
\text { dilakukan agar } \\
\text { aliran air dapat } \\
\text { mengalir } \\
\text { dengan lancar. } \\
\text { Pemeliharaan } \\
\text { ini bisa } \\
\text { dilakukan } \\
\text { dengan } \\
\text { pembersihan } \\
\text { saluran dari } \\
\text { sampah dan } \\
\text { endapan } \\
\text { sedimen. Jika } \\
\text { drainase tidak } \\
\text { dipelihara maka } \\
\text { akan } \\
\text { mempengaruhi } \\
\text { kapasitas } \\
\text { drainase }\end{array}$ & $\begin{array}{l}\text { S. } \\
\text { Pemeliharaan } \\
\text { drainase ini } \\
\text { berkaitan dengan } \\
\text { daya tampung } \\
\text { atau kapasitas } \\
\text { drainase itu } \\
\text { sendiri. Jika } \\
\text { drainase } \\
\text { terpelihara } \\
\text { dengan baik } \\
\text { maka aliran air } \\
\text { akan lancar } \\
\text { dalam jangka } \\
\text { waktu yang } \\
\text { lama. Jika tidak } \\
\text { kemungkinan } \\
\text { ada kerusakan } \\
\text { jaringan atau } \\
\text { mengecilnya } \\
\text { kapasitas } \\
\text { drainase yang } \\
\text { disebabkan oleh } \\
\text { sampah serta } \\
\text { pasir yang } \\
\text { menumpuk }\end{array}$ & $\begin{array}{l}\text { S. } \\
\text { Pemeliharaan } \\
\text { drainase sangat } \\
\text { diperlukan di DAS } \\
\text { Ampal karena } \\
\text { banyak terdapat } \\
\text { endapan } \\
\text { pasir/sedimen } \\
\text { yang harus } \\
\text { dibersihkan agar } \\
\text { drainase dapat } \\
\text { menampung air } \\
\text { secara maksimal }\end{array}$ & $\begin{array}{l}\text { S. } \\
\text { Pemeliharaan } \\
\text { drainase ini } \\
\text { dilakukan sebagai } \\
\text { salah satu upaya } \\
\text { penanganan banjir. } \\
\text { Biasanya dilakukan } \\
\text { dengan pengerukan } \\
\text { sedimen di DAS } \\
\text { Ampal guna } \\
\text { memperlancar } \\
\text { aliran air. Selain itu } \\
\text { pemeliharaan juga } \\
\text { dapat dilakukan } \\
\text { dengan perbaikan } \\
\text { jaringan yang rusak } \\
\text { maupun } \\
\text { pembersihan } \\
\text { sampah yang } \\
\text { menghalangi aliran } \\
\text { air }\end{array}$ & KONSENSUS \\
\hline \multirow[t]{2}{*}{3.} & \multirow[t]{2}{*}{ Tata Guna Lahan } & $\begin{array}{l}\text { Jarak Bangunan } \\
\text { di Sempadan } \\
\text { Sungai }\end{array}$ & $\begin{array}{l}\text { S } \\
\text { Jarak bangunan } \\
\text { ke sungai } \\
\text { mempengaruhi } \\
\text { banjir karena } \\
\text { hal ini juga } \\
\text { berpengaruh } \\
\text { terhadap lebar } \\
\text { penampang } \\
\text { sungai sungai }\end{array}$ & $\begin{array}{l}\text { S. } \\
\text { Jarak bangunan } \\
\text { ke sungai } \\
\text { mempengaruhi } \\
\text { banjir karena hal } \\
\text { ini juga } \\
\text { berpengaruh } \\
\text { terhadap lebar } \\
\text { penampang }\end{array}$ & $\begin{array}{l}\text { T. } \\
\text { Jarak bangunan } \\
\text { terhadap sungai } \\
\text { berpengaruh, } \\
\text { tetapi jarak } \\
\text { bangunan yang } \\
\text { berada } \\
\text { disempadan } \\
\text { dengan sungai } \\
\text { tidak berpengaruh }\end{array}$ & $\begin{array}{l}\text { S. } \\
\text { Jarak bangunan ke } \\
\text { sungai } \\
\text { mempengaruhi } \\
\text { banjir karena hal } \\
\text { ini juga } \\
\text { berpengaruh } \\
\text { terhadap lebar } \\
\text { penampang sungai. }\end{array}$ & ITERASI \\
\hline & & $\begin{array}{l}\text { Lokasi } \\
\text { Permukiman di } \\
\text { Sempadan Sungai }\end{array}$ & $\begin{array}{l}\text { S. } \\
\text { Permukiman di } \\
\text { bantaran sungai } \\
\text { dapat } \\
\text { menghambat } \\
\text { aliran air dan } \\
\text { juga } \\
\text { menyebabkan } \\
\text { berkurangnya } \\
\text { kawasan } \\
\text { resapan air } \\
\text { disekitar sungai } \\
\text { sehingga } \\
\text { menyebabkan } \\
\text { peningkatan } \\
\text { debit air yang } \\
\text { harus } \\
\text { ditampung oleh } \\
\text { sungai. }\end{array}$ & $\begin{array}{l}\text { S. } \\
\text { Adanya } \\
\text { permukiman di } \\
\text { bantaran sungai } \\
\text { dapat } \\
\text { menghambat } \\
\text { aliran air. } \\
\text { Permukiman di } \\
\text { sempadan sungai } \\
\text { ini juga } \\
\text { menyebabkan } \\
\text { berkurangnya } \\
\text { kawasan resapan } \\
\text { air disekitar } \\
\text { sungai sehingga } \\
\text { menyebabkan } \\
\text { peningkatan } \\
\text { debit air yang } \\
\text { harus ditampung } \\
\text { oleh sungai. }\end{array}$ & $\begin{array}{l}\text { S. } \\
\text { Lokasi } \\
\text { permukiman di } \\
\text { sempadan sungai } \\
\text { dapat } \\
\text { menghambat } \\
\text { aliran air. } \\
\text { Seharusnya pada } \\
\text { sempadan sungai } \\
\text { bisa dijadikan } \\
\text { jalur inspeksi yang } \\
\text { disiapkan untuk } \\
\text { pengerukan dan } \\
\text { jalur hijau untuk } \\
\text { menyerap air } \\
\text { hujan sehingga } \\
\text { memperkecil debit } \\
\text { air yang akan } \\
\text { masuk ke sungai } \\
\text { atau saluran air }\end{array}$ & $\begin{array}{l}\text { S. } \\
\text { Tata guna lahan di } \\
\text { sekitar sungai } \\
\text { didominasi oleh } \\
\text { permukiman, } \\
\text { dimana } \\
\text { permukiman ini } \\
\text { akan } \\
\text { mempengaruhi } \\
\text { kapasitas dan } \\
\text { kinerja saluran air. }\end{array}$ & KONSENSUS \\
\hline
\end{tabular}

Keterangan: $\mathrm{S}=$ setuju

$\mathrm{T}=$ tidak setuju 
Beberapa responden menyampaikan beberapa faktor tambahan yaitu air pasang laut yang dikemukakan oleh BAPPELITBANG, BPBD, dan Dinas PU dengan definisi operasional yang dimaksud yaitu aliran air laut yang masuk menuju sungai akibat pengaruh pasang surut (aliran balik/back water). Pada tahap eksplorasi analisis Delphi telah dilakukan eksplorasi dari berbagai responden terkait konfirmasi setiap faktor yang mempengaruhi banjir di DAS Ampal. Berdasarkan hasil kuesioner dan wawancara, beberapa variabel belum mencapai konsensus sehingga belum dapat disimpulkan variabel apa saja yang mempengaruhi banjir di DAS Ampal. Oleh karena itu, dilakukan iterasi kedua

2. Tahap Iterasi II, dilakukan iterasi terhadap 3 faktor yaitu faktor bentuk DAS, jarak bangunan di sempadan sungai, dan aliran balik. Adapun hasil dari iterasi ini yaitu faktor bentuk DAS belum mencapai konsensus, faktor aliran balik telah mencapai konsensus, dan faktor jarak bangunan di sempadan sungai juga mencapai konsensus dengan mengubah kalimatnya menjadi faktor jarak bangunan terhadap sungai.

3. Tahap Iterasi III, dilakukan iterasi terhadap faktor bentuk DAS namun belum mencapai konsensus sehingga dilakukan iterasi yang keempat

4. Tahap Iterasi IV, dilakukan iterasi terhadap faktor bentuk DAS dan telah mencapai konsensus.

Berdasarkan penjelasan tersebut maka dapat disimpulkan bahwa terdapat 22 faktor terkonfirmasi yaitu faktor yang mempengaruhi terjadinya banjir di DAS Ampal. Faktorfaktor ini terdiri dari 11 faktor internal dan 11 faktor eksternal yang meliputi :

Faktor Internal

a. Kapasitas sungai

b. Kapasitas draianse

c. Infiltrasi tanah

d. Tinggi aliran air

e. Limpasan air

f. Erosi

g. Sedimentasi

h. Luas DAS

i. Topografi

j. Morfometri

k. Vegetasi

Faktor Eksternal

a. Intensitas hujan

b. Tata guna lahan

c. Perilaku membuang sampah

d. Kawasan kumuh

e. Perencanaan sistem pengendalian banjir

f. Pemeliharaan bendali

g. Pemeliharaan drainase

h. Lokasi permukiman di sempadan sungai

i. Bentuk DAS

j. Jarak bangunan terhadap sungai

k. Aliran balik
C. Analisis Program Penanganan Banjir yang Dilakukan Pemerintah Kota Balikpapan Berdasarkan Faktor yang Berpengaruh Terhadap Terjadinya Banjir di DAS Ampal

Pada proses analisis program penanganan banjir yang telah dilakukan pemerintah Kota Balikpapan, digunakan faktor-faktor yang telah diperoleh dari hasil analisis sebelumnya. Faktor-faktor ini digunakan sebagai input pada proses ini yang menggunakan teknik analisis konten. Pada analisis ini dilakukan coding sebagai suatu langkah klasifikasi data berdasarkan kode berdasarkan transkrip wawancara yang telah disusun sebelumnya. Pengkodean ini dilakukan untuk mengetahui letak informasi dalam transkrip wawancara terkait program atau upaya penanganan banjir apa saja yang telah dilakukan pemerintah. Berdasarkan analisis ini maka dapat diketahui apakah program penanganan banjir di DAS Ampal yang dilakukan oleh instansi terkait sudah sesuai berdasarkan faktor-faktor yang mempengaruhi terjadinya banjir. Adapun pengkodean transkrip wawancara dapat dilihat pada lampiran F dan hasil pengkodean dapat dilihat pada tabel sebagai berikut.

Tabel 2

Hasil Pengkodean dalam Transkrip Wawancara

\begin{tabular}{|c|c|c|c|c|}
\hline \multicolumn{2}{|c|}{ Faktor Internal } & \multirow[t]{2}{*}{ Keterangan } & \multirow{2}{*}{$\begin{array}{l}\text { Sumber } \\
\text { Teks }\end{array}$} & \multirow{2}{*}{$\begin{array}{l}\text { Jumlah } \\
\text { Sumber } \\
\text { Teks }\end{array}$} \\
\hline Indikator & Faktor & & & \\
\hline \multirow[t]{5}{*}{$\begin{array}{l}\text { Kondisi } \\
\text { Sungai }\end{array}$} & \multirow[t]{5}{*}{$\begin{array}{l}\text { Kapasitas } \\
\text { Sungai }\end{array}$} & $\begin{array}{l}\text { Terkonfirmasi } \\
\text { sudah dilakukan } \\
\text { penanganan } \\
\text { banjir terkait } \\
\text { kapasitas sungai } \\
\text { yaitu } \\
\text { perluasan/pelebar } \\
\text { an Sungai Ampal } \\
\text { pada tahun 2017- } \\
2018\end{array}$ & $\begin{array}{l}\text { T1.1, } \\
\text { T1.2, } \\
\text { T1.3, } \\
\text { T1.4, } \\
\text { T2.16 }\end{array}$ & 5 \\
\hline & & $\begin{array}{l}\text { Pembersihan } \\
\text { gorong-gorong di } \\
\text { beberapa titik } \\
\text { jembatan Sungai } \\
\text { Ampal } \\
\end{array}$ & $\begin{array}{l}\text { T1.9, } \\
\text { T2.10 }\end{array}$ & 2 \\
\hline & & $\begin{array}{l}\text { Rencana } \\
\text { Normalisasi } \\
\text { Sungai Ampal }\end{array}$ & $\begin{array}{l}\text { T2.6, } \\
\text { T2.7 }\end{array}$ & 2 \\
\hline & & $\begin{array}{l}\text { Pengerukan } \\
\text { sedimen di } \\
\text { beberapa titik } \\
\text { Sungai Ampal } \\
2018-2019\end{array}$ & $\begin{array}{l}\text { T2.18, } \\
\text { T2.24, } \\
\text { T2.25, } \\
\text { T2.27 }\end{array}$ & 4 \\
\hline & & $\begin{array}{l}\text { Rencana } \\
\text { pengerukan } \\
\text { tahun } 2020\end{array}$ & $\mathrm{~T} 2.25$ & 1 \\
\hline \multirow[t]{2}{*}{$\begin{array}{l}\text { Kondisi } \\
\text { Drainase }\end{array}$} & \multirow[t]{2}{*}{$\begin{array}{l}\text { Kapasitas } \\
\text { Drainase }\end{array}$} & \begin{tabular}{lr}
\multicolumn{2}{l}{ Terkonfirmasi } \\
sudah dilakukan \\
penanganan \\
banjir $\quad$ terkait \\
kapasitas \\
drainase \\
pelebaran & \\
beberapa & di \\
drainase & \\
\end{tabular} & $\begin{array}{l}\text { T2.9, } \\
\text { T2.10, } \\
\text { T2.16 } \\
\text { T2.10 }\end{array}$ & 4 \\
\hline & & $\begin{array}{lr}\text { Pengerukan } & \\
\text { sedimen } & \text { di } \\
\text { beberapa } & \text { titik } \\
\end{array}$ & $\begin{array}{l}\text { T2.17, } \\
\text { T2.18 }\end{array}$ & 2 \\
\hline
\end{tabular}




\begin{tabular}{|c|c|c|c|c|c|c|c|c|c|}
\hline \multicolumn{2}{|c|}{ Faktor Internal } & \multirow[t]{2}{*}{ Keterangan } & \multirow{2}{*}{$\begin{array}{l}\text { Sumber } \\
\text { Teks }\end{array}$} & \multirow{2}{*}{$\begin{array}{l}\text { Jumlah } \\
\text { Sumber } \\
\text { Teks }\end{array}$} & \multicolumn{2}{|c|}{ Faktor Internal } & \multirow[t]{2}{*}{ Keterangan } & \multirow{2}{*}{$\begin{array}{l}\text { Sumber } \\
\text { Teks }\end{array}$} & \multirow{2}{*}{$\begin{array}{l}\text { Jumlah } \\
\text { Sumber } \\
\text { Teks }\end{array}$} \\
\hline Indikator & Faktor & & & & Indikator & Faktor & & & \\
\hline & & drainase & & & & & \multirow{2}{*}{$\begin{array}{lr}\text { upaya } & \text { ini } \\
\text { dilakukan } & \text { sejak } \\
\text { tahun 2017. } & \end{array}$} & & \\
\hline \multirow[t]{2}{*}{$\begin{array}{l}\text { Kondisi } \\
\text { Tanah }\end{array}$} & \multirow[t]{2}{*}{$\begin{array}{l}\text { Infiltrasi } \\
\text { Tanah }\end{array}$} & \multirow[b]{2}{*}{$\begin{array}{l}\text { Terkonfirmasi } \\
\text { sudah dilakukan } \\
\text { penanganan } \\
\text { banjir terkait } \\
\text { infiltrasi tanah } \\
\text { yaitu sosialiasai } \\
\text { dan pelatihan } \\
\text { terkait adaptasi } \\
\text { mitigasi } \\
\text { lingkungan } \\
\text { dengan } \\
\text { pembuatan } \\
\text { biopori, } \\
\text { penampungan air } \\
\text { hujan dan } \\
\text { penghijauan. }\end{array}$} & \multirow{2}{*}{$\begin{array}{l}\text { T3.13, } \\
\text { T3.14, } \\
\text { T3.23 }\end{array}$} & \multirow[t]{2}{*}{3} & & & & & \\
\hline & & & & & & & \multirow{2}{*}{$\begin{array}{l}\text { Untuk limpasan } \\
\text { air } \\
\text { diketahui bahan, } \\
\text { pemerintah juga } \\
\text { melakukan } \\
\text { evaluasi perijinan } \\
\text { penggunaan } \\
\text { lahan guna } \\
\text { mengurangi } \\
\text { timgkat } \\
\text { pengupasan } \\
\text { lahan } \\
\text { terjadi yang } \\
\text { berakibat yang } \\
\text { peningkatan } \\
\text { erosi, } \\
\text { sedimentasi dan } \\
\text { debit air yang } \\
\text { masuk } \\
\text { saluran. ke }\end{array}$} & \multirow[t]{2}{*}{ T3.16 } & \multirow[t]{2}{*}{1} \\
\hline \multirow[t]{8}{*}{$\begin{array}{l}\text { Debit } \\
\text { Banjir }\end{array}$} & \multirow[t]{6}{*}{$\begin{array}{l}\text { Tinggi Aliran } \\
\text { Air }\end{array}$} & \multirow{3}{*}{$\begin{array}{l}\text { Terkonfirmasi } \\
\text { sudah dilakukan } \\
\text { penanganan } \\
\text { banjir terkait } \\
\text { tinggi aliran air } \\
\text { yaitu } \\
\text { pemantauan } \\
\text { secara fluktuatif } \\
\text { terhadap } \\
\text { ketinggian air. } \\
\text { Pemantauan ini } \\
\text { dilakukan bukan } \\
\text { sebagai bentuk } \\
\text { upaya penanganan } \\
\text { banjir tetapi } \\
\text { sebagai kegiatan } \\
\text { mitigasi bencana } \\
\text { agar dapat } \\
\text { ditentukan } \\
\text { langkah evakuasi } \\
\text { atau tidak. }\end{array}$} & \multirow[t]{3}{*}{$\begin{array}{l}\text { T1.5, } \\
\text { T1.6, } \\
\text { T1.19 }\end{array}$} & \multirow[t]{3}{*}{3} & & & & & \\
\hline & & & & & \multirow[t]{6}{*}{$\begin{array}{l}\text { Kapasitas } \\
\text { Sungai/D } \\
\text { rainase }\end{array}$} & Erosi & $\begin{array}{l}\text { Terkonfirmasi } \\
\text { sudah dilakukan } \\
\text { penanganan } \\
\text { banjir terkait } \\
\text { erosi yaitu } \\
\text { evaluasi perijinan } \\
\text { penggunaan dan } \\
\text { lahan } \\
\text { penetapan } \\
\text { peraturan } \\
\text { kebijakan terkait } \\
\text { guna lahan. }\end{array}$ & $\begin{array}{l}\text { T3.16, } \\
\text { T3.24, } \\
\text { T3.25 }\end{array}$ & 3 \\
\hline & & & & & & \multirow[t]{5}{*}{ Sedimentasi } & \multirow{2}{*}{$\begin{array}{l}\text { Terkonfirmasi } \\
\text { sudah dilakukan } \\
\text { penanganan } \\
\text { banjir terkait } \\
\text { sedimentasi yaitu } \\
\text { pelebaran dan } \\
\text { pengerukan } \\
\text { sungai Ampal }\end{array}$} & \multirow{2}{*}{$\begin{array}{l}\text { T2.15. } \\
\text { T2.16, } \\
\text { T2.17, } \\
\text { T2.18, } \\
\text { T2.24, } \\
\text { T2.25, } \\
\text { T2.27 }\end{array}$} & \multirow[t]{2}{*}{7} \\
\hline & & \multirow{2}{*}{$\begin{array}{l}\text { Rencana } \\
\text { pemasangan } 35 \\
\text { flood warning } \\
\text { system (FWS) di } \\
\text { Kota Balikpapan } \\
\text { termasuk DAS } \\
\begin{array}{l}\text { Ampal guna } \\
\text { memantau } \\
\text { kenaikan air. }\end{array} \\
\end{array}$} & $\begin{array}{l}\text { T1.13, } \\
\text { T1.14 }\end{array}$ & \multirow[t]{2}{*}{2} & & & & & \\
\hline & & & & & & & \multirow{3}{*}{$\begin{array}{l}\text { Penetapan } \\
\text { kebijakan terkait } \\
\text { guna lahan dan } \\
\text { syarat } \\
\text { membangun } \\
\text { rumah yaitu } \\
\text { dalam } 1 \text { rumah } \\
\text { atau bangunan } \\
\text { harus memiliki } \\
\text { RTH minimal } \\
30 \% \text { dari total } \\
\text { luas lahan }\end{array}$} & \multirow[t]{3}{*}{ T3.25 } & \multirow[t]{3}{*}{1} \\
\hline & & $\begin{array}{l}\text { Pengerukan } \\
\text { sedimen }\end{array}$ & $\begin{array}{l}\mathrm{T} 2.27 \\
\mathrm{~T} 2.28\end{array}$ & 2 & & & & & \\
\hline & \multirow[t]{2}{*}{ Limpasan Air } & \multirow{2}{*}{$\begin{array}{l}\text { Terkonfirmasi } \\
\text { sudah dilakukan } \\
\text { penanganan } \\
\text { banjir terkait } \\
\text { limpasan air } \\
\text { yaitu pengerukan } \\
\text { sedimen dan } \\
\text { evaluasi } \\
\text { penggunaan } \\
\text { lahan. Guna } \\
\text { memperbesar } \\
\text { kapasitas saluran } \\
\text { maka dilakukan } \\
\text { pengerukan } \\
\text { sedimen yang } \\
\text { ada di saluran } \\
\text { tersebut dimana }\end{array}$} & \multirow[t]{2}{*}{$\begin{array}{l}\mathrm{T} 2.27 \\
\mathrm{~T} 2.28\end{array}$} & \multirow[t]{2}{*}{2} & & & & & \\
\hline & & & & & $\begin{array}{l}\text { Karakteri } \\
\text { stik DAS }\end{array}$ & Luas DAS & $\begin{array}{l}\text { Terkonfirmasi } \\
\text { sudah dilakukan } \\
\text { penanganan } \\
\text { banjir terkait luas } \\
\text { DAS yaitu } \\
\text { adanya rencana } \\
\text { pemasangan } \\
\text { Flood Warning } \\
\text { System (FWS) } \\
\text { untuk monitoring } \\
\text { kenaikan air di } \\
\text { Kota Balikpapan. }\end{array}$ & $\begin{array}{l}\text { T1.19, } \\
\text { T1.20 }\end{array}$ & 2 \\
\hline
\end{tabular}




\begin{tabular}{|c|c|c|c|c|c|c|c|c|c|}
\hline \multicolumn{2}{|c|}{ Faktor Internal } & \multirow[t]{2}{*}{ Keterangan } & \multirow{2}{*}{$\begin{array}{l}\text { Sumber } \\
\text { Teks }\end{array}$} & \multirow{2}{*}{$\begin{array}{l}\text { Jumlah } \\
\text { Sumber } \\
\text { Teks }\end{array}$} & \multicolumn{2}{|c|}{ Faktor Internal } & \multirow[t]{2}{*}{ Keterangan } & \multirow{2}{*}{$\begin{array}{l}\text { Sumber } \\
\text { Teks }\end{array}$} & \multirow{2}{*}{$\begin{array}{l}\text { Jumlah } \\
\text { Sumber } \\
\text { Teks }\end{array}$} \\
\hline Indikator & Faktor & & & & Indikator & Faktor & & & \\
\hline & \multirow[t]{2}{*}{ Bentuk DAS } & $\begin{array}{l}\text { Terkonfirmasi } \\
\text { sudah dilakukan } \\
\text { penanganan }\end{array}$ & \multirow[t]{2}{*}{$\begin{array}{l}\text { T1.19, } \\
\text { T1.20 } \\
\text { T1.21 }\end{array}$} & \multirow[t]{2}{*}{3} & & & \multicolumn{2}{|l|}{$\begin{array}{l}\text { intensitas hujan } \\
\text { yaitu monitoring } \\
\text { wilayah }\end{array}$} & \\
\hline & & $\begin{array}{lr}\text { banjir } & \text { terkait } \\
\text { bentuk DAS } \\
\text { yaitu pelebaran } \\
\text { sungai dan } \\
\text { pembuatan } \\
\text { saluran } \\
\text { berdasarkan } \\
\text { eksisting guna } \\
\text { lahan. }\end{array}$ & & & & & $\begin{array}{l}\text { Sosialisasi dan } \\
\text { pelatihan } \\
\text { pembuatan } \\
\text { penampungan air } \\
\text { hujan (program } \\
\text { kampung iklim) }\end{array}$ & $\begin{array}{l}\text { T3.5, } \\
\text { T3.9, } \\
\text { T3.10, } \\
\text { T3.11, } \\
\text { T3.12, } \\
\text { T3.13, } \\
\text { T3.14, } \\
\text { T3.22, } \\
\text { T3.23 }\end{array}$ & 9 \\
\hline & \multirow[t]{2}{*}{ Topografi } & $\begin{array}{l}\text { Terkonfirmasi } \\
\text { sudah dilakukan } \\
\text { penanganan } \\
\text { banjir terkait } \\
\text { topografi yaitu } \\
\text { pembuatan } \\
\text { saluran air sesuai } \\
\text { elevasi }\end{array}$ & $\begin{array}{l}\text { T1.19, } \\
\text { T1.20, } \\
\text { T1.21, } \\
\text { T1.22, } \\
\text { T1.23 }\end{array}$ & 5 & \multirow[t]{5}{*}{$\begin{array}{l}\text { Aktivitas } \\
\text { Manusia }\end{array}$} & \multirow[t]{3}{*}{$\begin{array}{ll}\text { Tata } & \text { Guna } \\
\text { Lahan } & \end{array}$} & \multirow{3}{*}{$\begin{array}{l}\text { Terkonfirmasi } \\
\text { sudah dilakukan } \\
\text { penanganan } \\
\text { banjir terkait tata } \\
\text { guna lahan yaitu } \\
\text { adanya kebijakan } \\
\text { terkait guna } \\
\text { lahan. Adapun } \\
\text { kebijakan } \\
\text { tersebut yaitu } \\
\text { adanya RTRW } \\
\text { dan Peraturan } \\
\text { Daerah yang } \\
\text { mengatur ijin } \\
\text { perumahan } \\
\text { dimana } \\
\text { dijelaskan bahwa } \\
\text { sebanyak 4,3\% } \\
\text { dari total luas } \\
\text { lahan perumahan } \\
\text { harus dibangun } \\
\text { bendali. }\end{array}$} & \multirow{3}{*}{\begin{tabular}{|l} 
T1.12, \\
T1,16, \\
T1.17, \\
T1.18, \\
T2.11, \\
T2.19, \\
T2.29, \\
T2.30, \\
T3.3, \\
T3.4, \\
T3.6 \\
T3.8, \\
T3.16, \\
T3.17, \\
T3.20, \\
T3.24, \\
T3.25, \\
T4.5, \\
T4.6, \\
T4.7, \\
T4.8, \\
T4.9, \\
T4.11, \\
T4.12,
\end{tabular}} & \multirow[t]{3}{*}{23} \\
\hline & & $\begin{array}{l}\text { Pembuatan } \\
\text { dokumen rencana } \\
\text { tata ruang yang } \\
\text { berbasiskan } \\
\text { DAS, dalam hal } \\
\text { ini dapat } \\
\text { diketahui bahwa } \\
\text { jika peraturan } \\
\text { tersebut berbasis } \\
\text { DAS berarti juga } \\
\text { memperhatikan } \\
\text { topografi dan } \\
\text { elevasi DAS } \\
\text { tersebut. }\end{array}$ & T4.13 & 1 & & & & & \\
\hline & \multirow[t]{2}{*}{ Morfometri } & \multirow[b]{2}{*}{$\begin{array}{l}\text { Terkonfirmasi } \\
\text { sudah dilakukan } \\
\text { penanganan } \\
\text { banjir terkait } \\
\text { morfometri yaitu } \\
\text { sama seperti } \\
\text { kapasitas melalui } \\
\text { pelebaran dan } \\
\text { pengerukan guna } \\
\text { memperbesar } \\
\text { dimensi saluran. }\end{array}$} & \multirow[t]{2}{*}{$\begin{array}{l}\text { T2.16, } \\
\text { T2.17 }\end{array}$} & \multirow[t]{2}{*}{2} & & & & & \\
\hline & & & & & & \multirow[t]{2}{*}{$\begin{array}{l}\text { Perilaku } \\
\text { Membuang } \\
\text { Sampah }\end{array}$} & \multirow{2}{*}{$\begin{array}{l}\text { Terkonfirmasi } \\
\text { sudah dilakukan } \\
\text { penanganan } \\
\text { banjir terkait } \\
\text { perilaku } \\
\text { membuang } \\
\text { sampah } \\
\text { diantaranya yaitu } \\
\text { edukasi } \\
\text { penyadaran cara } \\
\text { membuang } \\
\text { sampah kepada } \\
\text { masyarakat, } \\
\text { sosialiasai } \\
\text { kegiatan Pola } \\
\text { Hidup Bersih } \\
\text { Sehat (PHBS) } \\
\text { kepada } \\
\text { masyarakat }\end{array}$} & \multirow[t]{2}{*}{$\begin{array}{l}\text { T1.10, } \\
\text { T3.15, } \\
\text { T3.19 }\end{array}$} & \multirow[t]{2}{*}{3} \\
\hline & \multirow[t]{3}{*}{ Vegetasi } & $\begin{array}{l}\text { Terkonfirmasi } \\
\text { sudah dilakukan } \\
\text { penanganan } \\
\text { banjir terkait } \\
\text { vegetasi yaitu } \\
\text { pemberian izin } \\
\text { operasi } \\
\text { perusahaan } \\
\text { dengan } \\
\text { kompensasi }\end{array}$ & $\begin{array}{l}\text { T3.17, } \\
\text { T3.18 }\end{array}$ & 2 & & & & & \\
\hline & & $\begin{array}{l}\text { Rencana } \\
\text { normalisasi } \\
\text { Sungai Ampal }\end{array}$ & $\begin{array}{l}\text { T3.20, } \\
\text { T3.21 }\end{array}$ & 2 & & \multirow[t]{5}{*}{$\begin{array}{l}\text { Kawasan } \\
\text { Kumuh }\end{array}$} & \multirow{5}{*}{\begin{tabular}{lr}
\multicolumn{2}{l}{ Terkonfirmasi } \\
sudah dilakukan \\
penanganan \\
banjir terkait \\
kawasan kumuh \\
yaitu penyusunan \\
skema penertiban \\
sempadan sungai \\
yang juga \\
sebagai bagian \\
dari program \\
normalisasi
\end{tabular}} & \multirow[t]{5}{*}{$\begin{array}{l}\mathrm{T} 4.5, \\
\mathrm{~T} 4.6\end{array}$} & \multirow[t]{5}{*}{2} \\
\hline & & $\begin{array}{l}\text { Rencana } \\
\text { penghijauan } \\
\text { lingkungan }\end{array}$ & T3.23 & 1 & & & & & \\
\hline \multicolumn{2}{|c|}{ Faktor Eksternal } & Keterangan & Sumber & Nodes & & & & & \\
\hline Indikator & Faktor & & Teks & & & & & & \\
\hline $\begin{array}{l}\text { Curah } \\
\text { Hujan }\end{array}$ & $\begin{array}{l}\text { Intensitas } \\
\text { Hujan }\end{array}$ & $\begin{array}{l}\text { Terkonfirmasi } \\
\text { sudah dilakukan } \\
\text { penanganan } \\
\text { banjir terkait }\end{array}$ & T1.5 & 1 & & & & & \\
\hline
\end{tabular}




\begin{tabular}{|c|c|c|c|c|c|c|c|c|c|}
\hline \multicolumn{2}{|c|}{ Faktor Internal } & \multirow[t]{2}{*}{ Keterangan } & \multirow{2}{*}{$\begin{array}{l}\text { Sumber } \\
\text { Teks }\end{array}$} & \multirow{2}{*}{$\begin{array}{l}\text { Jumlah } \\
\text { Sumber } \\
\text { Teks }\end{array}$} & \multicolumn{2}{|c|}{ Faktor Internal } & \multirow[t]{2}{*}{ Keterangan } & \multirow{2}{*}{$\begin{array}{l}\text { Sumber } \\
\text { Teks }\end{array}$} & \multirow{2}{*}{$\begin{array}{l}\text { Jumlah } \\
\text { Sumber } \\
\text { Teks }\end{array}$} \\
\hline Indikator & Faktor & & & & Indikator & Faktor & & & \\
\hline & & Sungai Ampal. & & & & \multirow[t]{2}{*}{ Bendali } & \multirow[b]{2}{*}{$\begin{array}{c}\text { terkonfirmasi } \\
\text { belum } \\
\text { melakukan } \\
\text { pemeliharaan } \\
\text { bendali. Terdapat } \\
3 \text { bendali pada } \\
\text { DAS Ampal } \\
\text { namun belum } \\
\text { ada upaya } \\
\text { pemeliharaan } \\
\text { bendali. }\end{array}$} & \multirow{2}{*}{$\begin{array}{l}\mathrm{T} 2.21, \\
\mathrm{~T} 4.1, \\
\mathrm{~T} 4.2, \\
\mathrm{~T} 4.3, \\
\mathrm{~T} 4.4\end{array}$} & \\
\hline & \multirow[t]{2}{*}{$\begin{array}{l}\text { Perencanaan } \\
\text { Sistem } \\
\text { Pengendalian } \\
\text { Banjir }\end{array}$} & \multirow[t]{2}{*}{$\begin{array}{l}\text { Terkonfirmasi } \\
\text { sudah dilakukan } \\
\text { penanganan } \\
\text { banjir terkait } \\
\text { perencanaan } \\
\text { sistem } \\
\text { pengendalian } \\
\text { banjir yaitu } \\
\text { adanya rencana } \\
\text { pemasangan } 35 \\
\text { EWS. }\end{array}$} & \multirow[t]{2}{*}{$\begin{array}{l}\text { T1.13, } \\
\text { T1.14 }\end{array}$} & \multirow[t]{2}{*}{2} & & & & & \\
\hline & & & & & & \multirow{5}{*}{$\begin{array}{l}\text { Pemeliharaan } \\
\text { Drainase }\end{array}$} & \multirow[b]{2}{*}{$\begin{array}{l}\text { Terkonfirmasi } \\
\text { sudah dilakukan } \\
\text { penanganan } \\
\text { banjir terkait } \\
\text { pemeliharaan } \\
\text { drainase yaitu } \\
\text { pembersihan } \\
\text { gorong-gorong }\end{array}$} & \multirow{2}{*}{$\begin{array}{l}\text { T1.9, } \\
\text { T2.10 }\end{array}$} & \multirow[t]{2}{*}{2} \\
\hline & & \multirow[t]{2}{*}{$\begin{array}{l}\text { Adanya } \\
\text { penyusunan } \\
\text { MoU dengan } \\
\text { Pemerintah } \\
\text { Provinsi terkait } \\
\text { pembangunan } \\
\text { saluran drainase } \\
\text { primer }\end{array}$} & $\begin{array}{l}\text { T2.1, } \\
\text { T2.2 }\end{array}$ & \multirow[t]{2}{*}{2} & & & & & \\
\hline & & & & & & & \multirow{2}{*}{$\begin{array}{l}\text { Pengerukan } \\
\text { sedimen pada } \\
\text { drainase }\end{array}$} & \multirow{2}{*}{$\begin{array}{l}\text { T2.17, } \\
\text { T2.18 }\end{array}$} & \multirow[t]{2}{*}{2} \\
\hline & & \multirow{3}{*}{$\begin{array}{l}\text { Adanya program } \\
\text { normalisasi } \\
\text { Sungai Ampal } \\
\text { yang hingga saat } \\
\text { ini belum } \\
\text { terlaksana karena } \\
\text { masih dalam } \\
\text { tahap } \\
\text { pembebasan } \\
\text { lahan. Namun } \\
\text { telah diusulkan } \\
\text { sebagai proyek } \\
\text { strategis nasional }\end{array}$} & \multirow{3}{*}{$\begin{array}{l}\text { T2.6, } \\
\text { T2.7, } \\
\text { T2.14, } \\
\text { T4.10 }\end{array}$} & \multirow[t]{3}{*}{4} & & & & & \\
\hline & & & & & & & $\begin{array}{l}\text { Pelatihan cara } \\
\text { pembuatan } \\
\text { saluran air } \\
\text { beserta } \\
\text { pemeliharannya }\end{array}$ & $\mathrm{T} 1.11$ & 1 \\
\hline & & & & & \multirow[t]{6}{*}{$\begin{array}{l}\text { Tata } \\
\text { Guna } \\
\text { Lahan }\end{array}$} & \multirow[t]{4}{*}{$\begin{array}{l}\text { Jarak } \\
\text { Bangunan } \\
\text { terhadap } \\
\text { Sungai }\end{array}$} & \multirow{4}{*}{$\begin{array}{l}\text { Terkonfirmasi } \\
\text { sedang dilakukan } \\
\text { penanganan } \\
\text { banjir terkait } \\
\text { jarak bangunan } \\
\text { terhadap sungai } \\
\text { yaitu melalui } \\
\text { upaya } \\
\text { pembebasan } \\
\text { lahan sebagai } \\
\text { bagian dari } \\
\text { normalisasi } \\
\text { Sungai Ampal. } \\
\text { Namun upaya } \\
\text { normalisasi ini } \\
\text { belum } \\
\text { direalisasikan, } \\
\text { hingga saat ini } \\
\text { masih berupa } \\
\text { kajian/rencana } \\
\text { dikarenakan } \\
\text { terhambat oleh } \\
\text { pembebasan } \\
\text { lahan. }\end{array}$} & \multirow[t]{4}{*}{$\begin{array}{l}\text { T2.30, } \\
\text { T3.21 }\end{array}$} & \multirow[t]{4}{*}{2} \\
\hline & & $\begin{array}{l}\text { Adanya rencana } \\
\text { pembangunan } \\
\text { bendali } \\
\text { belakang Pasar } \\
\text { Segar atau di } \\
\text { hulu Sungai } \\
\text { Ampal pada } \\
\text { tahun 2021 }\end{array}$ & $\begin{array}{l}\mathrm{T} 2.12, \\
\mathrm{~T} 2.26\end{array}$ & 2 & & & & & \\
\hline & & $\begin{array}{l}\text { Adanya kajian } \\
\text { penanganan } \\
\text { banjir pada tahun } \\
\text { 2019 terkait RTH } \\
\text { di DAS Ampal }\end{array}$ & $\begin{array}{l}\text { T3.1, } \\
\text { T3.2, } \\
\text { T3.3, } \\
\text { T3.4, } \\
\text { T3.5, } \\
\text { T3.25, } \\
\text { T4.7, } \\
\text { T4.16 }\end{array}$ & 8 & & & & & \\
\hline & & \multirow[b]{2}{*}{$\begin{array}{l}\text { Penyusunan } \\
\text { RTRW berbasis } \\
\text { DAS serta } \\
\text { pengendalian tata } \\
\text { guna lahan yang } \\
\text { disesuaikan } \\
\text { dengan } \\
\text { masterplan } \\
\text { drainase kota } \\
\text { termasuk upaya } \\
\text { pembangunan } \\
\text { bendali yang } \\
\text { diintergrasikan } \\
\text { dengan perizinan } \\
\text { site plan } \\
\text { pengembangan } \\
\text { perumahan }\end{array}$} & \multirow{2}{*}{$\begin{array}{l}\mathrm{T} 4.11, \\
\mathrm{~T} 4,12, \\
\mathrm{~T} 4.13, \\
\mathrm{~T} 4,14\end{array}$} & \multirow[t]{2}{*}{4} & & & & & \\
\hline & & & & & & \multirow[t]{2}{*}{$\begin{array}{l}\text { Lokasi } \\
\text { Permukiman } \\
\text { di Sempadan } \\
\text { Sungai }\end{array}$} & \multirow[t]{2}{*}{$\begin{array}{l}\text { Terkonfirmasi } \\
\text { sedang } \\
\text { melakukan upaya } \\
\text { penanganan } \\
\text { banjir terkait } \\
\text { lokasi } \\
\text { permukiman di } \\
\text { sempadan } \\
\text { sungai. Diketahui } \\
\text { bahwa } \\
\text { pemerintah } \\
\text { sedang } \\
\text { melakukan upaya } \\
\text { penertiban lokasi } \\
\text { permukiman di } \\
\text { sempadan sungai }\end{array}$} & $\begin{array}{l}\text { T2.30, } \\
\text { T4.5, } \\
\text { T4.6 }\end{array}$ & 3 \\
\hline & Pemeliharaan & Pemerintah & $\mathrm{T} 2.20$ & 6 & & & & & \\
\hline
\end{tabular}




\begin{tabular}{|c|c|c|c|c|}
\hline \multicolumn{2}{|c|}{ Faktor Internal } & \multirow[t]{2}{*}{ Keterangan } & \multirow{2}{*}{$\begin{array}{l}\text { Sumber } \\
\text { Teks }\end{array}$} & \multirow{2}{*}{$\begin{array}{l}\text { Jumlah } \\
\text { Sumber } \\
\text { Teks }\end{array}$} \\
\hline Indikator & Faktor & & & \\
\hline & & $\begin{array}{l}\text { melalui } \\
\text { pembebasan } \\
\text { lahan dimana } \\
\text { upaya ini } \\
\text { merupakan } \\
\text { bagian dari } \\
\text { program } \\
\text { normalisasi } \\
\text { Sungai Ampal. } \\
\end{array}$ & & \\
\hline \multirow[t]{2}{*}{$\begin{array}{l}\text { Air } \\
\text { Pasang } \\
\text { Laut }\end{array}$} & Aliran Balik & $\begin{array}{l}\text { Terkonfirmasi } \\
\text { sudah melakukan } \\
\text { penanganan } \\
\text { banjir terkait } \\
\text { aliran balik yaitu } \\
\text { dengan } \\
\text { monitoring } \\
\text { kenaikan air. }\end{array}$ & $\begin{array}{l}\text { T1.5, } \\
\text { T1.6, } \\
\text { T1.19 }\end{array}$ & 3 \\
\hline & & $\begin{array}{l}\text { Rencana } \\
\text { pemasangan } 35 \\
\text { Flood Warning } \\
\text { System (FWS) di } \\
\text { Kota Balikpapan } \\
\text { namun belum } \\
\text { terealisasi. }\end{array}$ & $\begin{array}{l}\text { T1.13, } \\
\text { T1.14 }\end{array}$ & 2 \\
\hline
\end{tabular}

Keterangan :

T1 : sumber teks wawancara BPBD

T2 : sumber teks wawancara Dinas PU

T3 : sumber teks wawancara DLH

T4 : sumber teks wawancara BAPPELITBANG

Berdasarkan hasil wawancara diketahui bahwa program penanganan banjir di DAS Ampal yang dilakukan telah sesuai dengan faktor penyebab banjir. Secara keseluruhan dari hasil wawancara dapat diketahui bahwa pemerintah mampu mengidentifikasi dan merencanakan penanganan banjir pada DAS Ampal namun terdapat beberapa rencana yang belum ditindak lanjuti. Contohnya program normalisasi Sungai Ampal, pemasangan 35 flood warning system, program kampung iklim, dan program pembangunan 13 bendali pada DAS Ampal di mana hal tersebut sudah direncanakan oleh pemerintah namun hingga tahun 2020 program-program tersebut belum terealisasi di DAS Ampal. Dari hasil analisis ini diketahui pula bahwa terdapat beberapa program penanganan banjir yang telah dilakukan oleh pemerintah namun program tersebut belum dapat dalam menangani banjir di DAS Ampal. Program tersebut terdiri dari pelebaran sungai/drainase, pengerukan sedimen, evaluasi perijinan penggunaan lahan, pemberian izin operasi perusahaan dengan kompensasi, dan pelaksanaan peraturan tata ruang berdasarkan Dokumen RTRW Kota Balikpapan. Selain itu, diketahui bahwa terdapat 1 faktor penyebab banjir dimana pemerintah belum melakukan penanganan banjir terhadap faktor pemeliharaan bendali

\section{KESIMPULAN/RINGKASAN}

Berdasarkan analisis yang telah dilakukan, ditemukan 22 faktor (11 faktor internal dan 11 faktor eksternal) yang dapat memengaruhi terjadinya banjir di DAS Ampal yang terkonfirmasi dari ke 4 stakeholder pemerintah menggunakan analisis Delphi. Faktor ini terdiri dari faktor internal yaitu kapasitas sungai, kapasitas drainase, infiltrasi tanah, tinggi aliran air, limpasan air, erosi, sedimentasi, luas DAS, bentuk DAS, topografi, morfometri, vegetasi dan faktor eksternal yaitu intensitas hujan, tata guna lahan, perilaku membuang sampah, kawasan kumuh, perencanaan sistem pengendalian banjir, pemeliharaan bendali, pemeliharaan drainase, jarak bangunan terhadap sungai, lokasi permukiman di sempadan sungai, serta aliran balik (back water). Berdasarkan hasil analisis konten dapat diketahui bahwa pemerintah mampu mengidentifikasi dan merencanakan penanganan banjir pada DAS Ampal berdasarkan faktor penyebab banjir. Artinya secara keseluruhan program penanganan banjir yang dilakukan telah sesuai dengan faktor penyebab banjir. Namun, diperoleh beberapa temuan yaitu:

a. Terdapat beberapa rencana yang belum ditindaklanjuti padahal rencana ini merupakan penanganan banjir berdasarkan faktor kapasitas sungai, kapasitas drainase, infiltrasi tanah, tinggi aliran air, limpasan air, erosi, sedimentasi, luas DAS, bentuk DAS, topografi, morfometri, vegetasi, curah hujan, tata guna lahan, perilaku membuang sampah, kawasan kumuh, pemeliharaan drainase, lokasi permukiman di sempadan sungai, jarak bangunan terhadap sungai, dan aliran balik. Program yang belum ditindaklanjuti ini terdiri dari program normalisasi Sungai Ampal, pemasangan 35 flood warning system, program kampung iklim, dan program pembangunan 13 bendali pada DAS Ampal

b. Terdapat program yang telah dilakukan oleh pemerintah namun program tersebut belum dapat menangani banjir di DAS Ampal. Program tersebut terdiri dari pelebaran sungai/drainase, pengerukan sedimen, evaluasi perijinan penggunaan lahan, pemberian izin operasi perusahaan dengan kompensasi, dan pelaksanaan rencana tata ruang Kota Balikpapan

c. Pemerintah belum melakukan penanganan banjir dalam lingkup faktor pemeliharaan bendali

\section{UCAPAN TERIMA KASIH}

Terima kasih kami sampaikan kepada seluruh stakeholder yang terlibat yaitu BAPPELITBANG Kota Balikpapan, Dinas Pekerjaan Umum Kota Balikpapan, Dinas Lingkungam Hidup Kota Balikpapan, dan BPBD Kota Balikpapan yang telah membantu dalam penelitian ini.

\section{DAFTAR PUSTAKA}

[1] R. M. K. Yanti, R. D. Anugrah, and ..., "EVALUASI KAPASITAS SALURAN SUB DAS AMPAL KOTA BALIKPAPAN," ... Kaji. Tek. SIPIL, 2019.

[2] R. M. Kadar Yanti, E. Edijatno, and U. Lasminto, "DAS Ampal Analisa Fungsi dan Pengaruh Bangunan Pengendali Banjir DAS 
Ampal Kota Balikpapan,” SPECTA J. Technol., 2018, doi: 10.35718/specta.v2i3.10.

[3] Yanti, Rossana, dkk. (2019), "Analisa Fungsi dan Pengaruh Bangunan Pengendali Banjir DAS Ampal Kota Balikpapan”. Jurnal Kajian Teknik Sipil, Vol. 04, No. 2.

[4] Badan Pusat Statistik. 2016. Kota Balikpapan Dalam Angka Tahun 2016. Kota Balikpapan

[5] Badan Pusat Statistik. 2017. Kota Balikpapan Dalam Angka Tahun 2017. Kota Balikpapan

[6] BNPB, "Potensi dan Ancaman Bencana," BNPB, 2017.

[7] F. Ibrahim, F. Atriani, T. R. Wulan, M. D. Putra, and E. Maulana, "Upaya Pengurangan Risiko Bencana Terkait Perubahan Iklim Mitigasi Bencana Erosi Kepesisiran di Pantai Kuwaru dan Samas, Kabupaten Bantul DIY,” Pros. Semin. Nas. Geogr. UMS, 2016.

[8] D. Arif, D. Mardiatna, and S. R. Giyarsih, "Kerentanan Masyarakat Perkotaan terhadap Bahaya Banjir,” Maj. Geogr. Indones., 2017.

[9] Pemerintah Kota Balikpapan. Laporan Akhir Kajian Penanganan Banjir di Kota Balikpapan. 2019. Balikpapan

[10] E. H. Pongtuluran and M. Huda, "EVALUASI KINERJA KAPASITAS SALURAN DRAINASE RAWAN BANJIR KOTA BALIKPAPAN (STUDI KASUS PERUMAHAN GRAHA POLTEKBA)," J. Dyn. Saint, 2020, doi: 10.47178/dynamicsaint.v4i2.873. 